\title{
BIBLIOGRAFIJA PROF. DR. MIRKA PAKA
}

\section{Znanstveni prispevki}

Kolonizacija Slovencev v Banatu. Geografski zbornik 8 (1963), str. 395-428.

Današnji gospodarski pomen izgonov na Zgornjem Dravskem polju. Geografski vestnik 36 (1964), str. 75-79.

Razvoj posestnih razmer kmečkega zemljišča na Zgornjem Dravskem polju. Časopis za zgodovino in narodopisje 37 (1966), str. 178-191.

Socialno geografska transformacija nekaterih mestnih četrti Ljubljane in Maribora. Geografski vestnik 38 (1967), str. 123-142.

Strukturalna in fiziognomska analiza transformacije delov nekaterih mestnih četrti Maribora. Socialnogeografska raziskava. Časopis za zgodovino in narodopisje 39 (1968), str. 223-235.

Transformacija na selskoto stopanstvo i iskoristuvanje na zemjišteto vo Golozinci. Geografski razgledi 6 (1968), str. 37-54. (Soavtorja: Vladimir Klemenčič, Mitko Panov)

Družbenogeografski razvoj Zgornjega Dravskega polja. Geografski zbornik 11 (1969), str. 281-404.

Nekateri elementi gospodarsko-geografskega razvoja Rakitne. Geografski vestnik 41 (1969), str. 39-59. (Soavtor Vladimir Klemenčič)

Geografski učinki socialne deformacije v nekaterih predelih slovenskih mest. Geografski vestnik 43 (1971), str. 123-133. (Soavtor Gojmir Bervar)

Preobrazba »čaršije« v Bitoli. Socialnogeografska raziskava starega obrtniško-trgovskega mestnega središča. Geografski vestnik 43 (1971), str. 97-121.

Trgovska središča v Ljubljani, Mariboru in Kranju. Nekaj geografskih elementov v organizaciji oskrbe. Geografski vestnik 45 (1973), str. 47-70.

Oskrba kot predmet geografskega proučevanja. Geografski vestnik 49 (1977), str. $183-188$.

Einige Elemente der sozioökonomischen Struktur der Stadt Ohrid. V: Räumliche Struktur- und Prozeßmuster in der SR Makedonien. Kallmünz/Regensburg, M. Lassleben, 1980, str. 65-73. (Münchner Studien zur Sozial- und Wirtschaftsgeographie, 20)

Geografska problematika demogeografskega razvoja, industrije in oskrbnega omrežja v obmejnem območju zahodne Slovenije. V: Raziskovalno delo Inštituta za geografijo Univerze Edvarda Kardelja. Ljubljana, Inštitut za geografijo Univerze Edvarda Kardelja, 1981, str. 107-139. (Geographica Slovenica, 12)

Nekaj misli o položaju v slovenski geografiji. Anthropos 1981, št. 4/6, str. 325-335.

Problematika geografskega proučevanja oskrbe. V: 20 let socialne geografije v Sloveniji. Ljubljana, Inštitut za geografijo Univerze Edvarda Kardelja, 1982, str. 116-124. (Geographica Slovenica, 13)

Die Funktion der Versorgung bei der Ausbildung der Regionalstruktur Sloweniens. V: Beiträge zur Landeskunde von Friaul-Julisch Venetien, Kärnten und Slowenien. Klagenfurt, Institut für Geographie der Universität Klagenfurt, 1983, str. 51-56. (Klagenfurter Geographische Schriften, 4) 
Oskrba v regionalni strukturi Slovenskega Alpskega sveta. V: Usmerjanje regionalnega razvoja Slovenije. Slovenske Alpe, severovzhodna Slovenija, Bela. Ljubljana, Inštitut za geografijo Univerze Edvarda Kardelja, 1983, str. 19-28. (Geographica Slovenica, 14)

Regional geographical characteristics of the Upper Soča Valley. Geographica Iugoslavica (1983), št. 5, str. 99-105.

Die Versorgungsfunktion in den Slowenischen Alpen. V: Raumstrukturen der randalpinen Bereiche Bayerns und Sloweniens. Kallmünz/Regensburg, M. Lassleben, 1984, str. 49-56. (Münchner Studien zur Sozial- und Wirtschaftsgeographie, 27; Südosteuropa-Studien, 36)

Problematika trgovine na Gorenjskem. Geografski vestnik 58 (1986), str. 43-54. (Soavtor Valentin Trilar)

Prostorska organizacija družbene infrastrukture v občini Ravne s posebnim ozirom na KS Črna. V: Geografsko proučevanje uvajanja celične proizvodnje na Koroškem. Ljubljana, Oddelek za geografijo; Znanstveni inštitut Filozofske fakultete Univerze Edvarda Kardelja, 1986, str. 61-65. (Dela, 2)

Urbana geografija in etnologija. V: O razmerju med geografijo in etnologijo. Ljubljana, Oddelek za geografijo; Znanstveni inštitut Filozofske fakultete, 1986, str. 65-68. (Dela, 3)

Nekateri elementi zgradbe in ustroja mestnega središča Maribor. Časopis za zgodovino in narodopisje 23 (1987), št. 1, str. 3-20.

Neke misli o stanju urbane geografije u Jugoslaviji. Geografski glasnik 49 (1987), str. 37-40.

Problematika trgovine u Gorenjskoj. Nova trgovina 11 (1987), št. 6, str. 317-322.

Der Ursprung der Bevölkerung in den slowenischen Städten. V: Socialna geografija in regionalni razvoj. Ljubljana, Oddelek za geografijo Filozofske fakultete; Znanstveni inštitut Filozofske fakultete, 1987, str. 1-11. (Dela, 5)

Transformation of the coastal region in the Koper littoral. The case of land utilization in the cadastral commune of Sečovlje. Geographica Iugoslavica 1989, št. 10/11, str. $121-128$.

Novejši trendi urbanizacije na Dravskem polju. Znanstvena revija. Družboslovje in filozofija 2 (1990), št. 2, str. 187-195.

Problematika delavskih predelov kot element mestne zgradbe s posebnim ozirom na Maribor. V: Urejanje prostora 2. Pregled novejših raziskav. Ljubljana, Urbanistični inštitut Republike Slovenije, 1990, str. 20-22. (Publikacija časopisa Urbani izziv)

Nekateri elementi razvoja prebivalstva Maribora. Geografski vestnik 63 (1991), str. 81-96.

Socialnogeografska problematika »delavskih« predelov v zgradbi industrijskih središč. Na primeru Maribora. Časopis za zgodovino in narodopisje 62 (1991), št. 1, str. 15-24.

Elemente demographischer Entwicklung in der Struktur der Stadt Maribor. V: Slowenien auf dem Weg in die Marktwirtschaft. Bayreuth, Universität Bayreuth, 1992, str. 51-67. (Arbeitsmaterialien zur Raumordnung und Raumplanung, 108)

Elementi socialnogeografskega razvoja na Dravskem polju. V: Socialna geografija v teoriji in praksi. Ljubljana, Inštitut za geografijo Univerze v Ljubljani, 1992, str. 139148. (Geographica Slovenica, 23) 
Die Entwicklung, Funktion und Struktur von Maribor. Jahrbuch/Marburger geographische Gesellschaft, 1992, str. 174-177.

The main geographic facts of Slovenia. V: Slovenia, geographic aspects of a new independent European nation. Ljubljana, Zveza geografskih društev Slovenije, 1992, str. 5-8.

Neuere Prozesse in der Regionalentwicklung im Dravsko polje (Draufeld) in der Nähe von Maribor. V: Slowenien auf dem Weg in die Marktwirtschaft. Bayreuth, Universität Bayreuth, 1992, str. 88-97. (Arbeitsmaterialen zur Raumordnung und Raumplanung, 108)

Settlements in Slovenia. V: Slovenia, geographic aspects of a new independent European nation. Ljubljana, Zveza geografskih društev Slovenije, 1992, str. 93-99.

Bevölkerungsentwicklung und -struktur. V: Marburg - Maribor. Geographische Beiträge über die Partnerstädte in Deutschland und Slowenien. Marburg/Lahn, Marburger geographische Gesellschaft, 1994, str. 202-223. (Marburger geographische Schriften, 126; Marburger Stadtschriften zur Geschichte und Kultur, 48)

Gospodarska problematika Maribora. V: Maribor - Marburg. Prispevki h geografiji prijateljskih mest v Sloveniji in Nemčiji. Maribor, Pedagoška fakulteta, 1994, str. 84-100. (Soavtorica Andrejka Slavec)

Položaj Maribora in upravna členitev. V: Maribor - Marburg. Prispevki h geografiji prijateljskih mest v Sloveniji in Nemčiji. Maribor, Pedagoška fakulteta, 1994, str. 40-44.

Razvoj in struktura prebivalstva. V: Maribor - Marburg. Prispevki h geografiji prijateljskih mest v Sloveniji in Nemčiji. Maribor, Pedagoška fakulteta, 1994, str. 57-77.

Slowenien. V: Zentrensysteme als Träger der Raumentwicklung in Mittel- und Osteuropa. Leipzig, Institut für Länderkunde, 1994, str. 116-118. (Beiträge zur regionalen Geographie, 37) (Soavtorica Evelin Müller)

Die Stadtstruktur. V: Marburg - Maribor. Geographische Beiträge über die Partnerstädte in Deutschland und Slowenien. Marburg/Lahn, Marburger geographischen Gesellschaft, 1994, str. 190-201. (Marburger geographische Schriften, 126; Marburger Stadtschriften zur Geschichte und Kultur, 48). (Soavtor Vladimir Drozg)

Verwaltungsgliederung und Funktion. V: Marburg - Maribor. Geographische Beiträge über die Partnerstädte in Deutschland und Slowenien. Marburg/Lahn, Marburger geographische Gesellschaft, 1994, str. 185-189. (Marburger geographische Schriften, 126; Marburger Stadtschriften zur Geschichte und Kultur, 48)

Wirtschaftsstruktur und -entwicklung. V: Marburg - Maribor. Geographische Beiträge über die Partnerstädte in Deutschland und Slowenien. Marburg/Lahn, Marburger geographische Gesellschaft, 1994, str. 230-247. (Marburger geographische Schriften, 126; Marburger Stadtschriften zur Geschichte und Kultur, 48) (Soavtorica Andrejka Slavec)

Zgradba mesta. V: Maribor - Marburg. Prispevki h geografiji prijateljskih mest v Sloveniji in Nemčiji. Maribor, Pedagoška fakulteta, 1994, str. 45-54. (Soavtor Vladimir Drozg)

Nekateri geografski elementi zgradbe Kranja. Kranjski zbornik 1995, str. 149-159.

Reshaping of the trans-border cooperation in Slovenia. V: Local and regional development during the 1990s transition in Eastern Europe. Aldershot, Avebury, 1995, str. 99-107. 
Socialnogeografska zgradba slovenskih mest na kvalitetnem prehodu. V: Geografska problematika slovenskega alpskega sveta in slovenskih mest. Ljubljana, Oddelek za geografijo Filozofske fakultete, 1995, str. 121-129. (Dela, 11)

Some elements of regional development in Slovenia. Regional contact 9 (1995), št. 10, str. 88-91.

Umwandlung der slowenischen Städte. V: Városok, vonzáskörzetek, határmenti térségek $=$ Towns, districts attraction, border regions $=$ Städte, Bezugskreise, Grenzregionen . Pécs, Janus Pannonius Tudományegyetem Földrajzi Tanszékek, 1995, str. 87-99.

Dravska ravnina. V: Regionalnogeografska monografija Slovenije. 9. del, Severni subpanonski svet. Ljubljana, Znanstvenoraziskovalni center SAZU, Geografski inštitut, 1996, str. 147-173.

Geografski elementi regionalnega razvoja Spodnjega Podravja s Prlekijo. Geografski vestnik 68 (1996), str. 161-174.

Kranj. V: Regionalnogeografska monografija Slovenije. 3. del. Ljubljanska kotlina. Ljubljana, Znanstvenoraziskovalni center SAZU, Geografski inštitut, 1996, str. 114-124.

Ljubljanska kotlina. V: Regionalnogeografska monografija Slovenije. 3. del. Ljubljanska kotlina. Ljubljana, Znanstvenoraziskovalni center SAZU, Geografski inštitut, 1996, str. $2-9$.

Ljubljansko polje in Ljubljana. V: Regionalnogeografska monografija Slovenije. 3. del. Ljubljanska kotlina. Ljubljana, Znanstvenoraziskovalni center SAZU, Geografski inštitut, 1996, str. 70-86.

Maribor. V: Regionalnogeografska monografija Slovenije. 9. del, Severni subpanonski svet. Ljubljana, Znanstvenoraziskovalni center SAZU, Geografski inštitut, 1996, str. 123-146.

Vpliv univerze na razvoj Ljubljane. V: Socialnogeografski problemi. Posvečeno 70. letnici prof. Vladimirja Klemenčiča. Ljubljana, Oddelek za geografijo Filozofske fakultete, 1997, str. 215-227. (Dela, 12)

Demografske prvine regionalnega razvoja ob slovensko-avstrijski meji. V: Raziskovanje kulturne ustvarjalnosti na Slovenskem. Šumijev zbornik. Ob dvajsetletnici Znanstvenega inštituta. Ljubljana, Znanstveni inštitut Filozofske fakultete, 1999, str. 251-263. (Razprave Filozofske fakultete)

Globalizacija in razvoj slovenskih mest. V: Razvojne možnosti Slovenije. Bodočnost mest. 80. letnica Oddelka za geografijo. Ljubljana, Oddelek za geografijo Filozofske fakultete, 1999, str. 131-135. (Dela, 14)

Market economy and transformation of Slovenian cities. A case study of Ljubljana. V: Problems of megacities. Social inequalities, environmental risk and urban governance. Mexico City, Universidad nacional autónoma de México, Institute of geography, 1999, str. 111-116.

Problematik der Regionalentwicklung Sloweniens. Österreich in Geschichte und Literatur 43 (1999), št. 2, str. 96-106.

Problems of agriculture in Slovenia with special reference to Cirkovce. GeoJournal 46 (1999), št. 3, str. 257-261. (Soavtorica Valentina Brečko Grubar)

Funkcijska zgradba. V: Ljubljana. Geografija mesta. Ljubljana, Ljubljansko geografsko društvo; Založba ZRC, ZRC SAZU, 2000, str. 53-58. 
Problematika razvoja oskrbnega središča Kranja. Kranjski zbornik 2000, str. 197-206. (Soavtorica Andrejka Slavec)

Urban system in Slovenia. The recent most developmental trends. V: Integrated urban systems and sustainability of urban life. Bucureşti, Editura tehnică, 2000, str. 227-232.

Funkcijska zgradba Ljubljane. V: Geografija Ljubljane. Ljubljana, Oddelek za geografijo Filozofske fakultete, 2002, str. 133-149.

Problematic of the functional structure of Slovene cities. Dela 2004, št. 21, str. 131-137. Specifični elementi v funkcijski zgradbi Ljubljane. Dela 2004, št. 22, str. 27-37.

Problematika razvoja mest in spreminjanja rabe mestnega prostora. Dela 2005, št. 24, str. 159-170. (Soavtorica Angelca Rus)

Prostorski razvoj Kranja v 20. stoletju. Kranjski zbornik 2005, str. 115-122. (Soavtorica Andrejka Slavec)

Some problems of Slovene cities in capitalist economy. Geografski radovi 2005, št. 1, str. $102-110$.

Oskrbne funkcije v organizaciji mestnega prostora - na primeru Maribora. Dela 2007, št. 27, str. 69-80.

Kooperation slowenischer und deutscher Geographen. V: Slowenien. Transformationen und kleinräumige Vielfalt. Frankfurt am Main, Institut für Humangeographie, 2008, str. 318-336. (Natur-Raum-Gesellschaft, 5)

Svetlejša prihodnost slovenske regionalne geografije. Dela 2009, št. 32, str. 5-17.

Introducing Ljubljana. V: Challenges of spatial development of Ljubljana and Belgrade, Ljubljana, Scientific Publishing House of the Faculty of Arts, 2010, str. 9-16. (GeograFF, 8)

Razvojna problematika Haloz na primerih katastrskih občin Gorca in Slatina. Dela 2010, št. 34, str. 91-114. (Soavtor Vladimir Korošec)

Razvojna problematika oskrbnih središč Ptuja in Ormoža. V: Spodnje Podravje pred izzivi trajnostnega razvoja. Ljubljana, Znanstvena založba Filozofske fakultete, 2011, str. 59-75. (GeograFF, 9)

\section{Prispevki na konferencah}

Uticaji industrijskih centara na agrarnu okolicu na primeru Gornjeg Dravskog polja. V: Zbornik radova Prvog jugoslavenskog simpozija o agrarnoj geografiji u Mariboru od 3. do 5. decembra 1964. Zbornik posvećen 60-godišnjici rođenja Svetozara Ilešiča. Ljubljana, Inštitut za geografijo Univerze; Maribor, Združenje visokošolskih zavodov, 1967, str. 118-121.

Sodobni procesi v preoblikovanju mestnih četrti. V: Zbornik na VIII kongres na geografite od SFRJ vo Makedonija od 9. IX. do 14. IX. 1968. Skopje, Sojuz na geografskite društva na SFRJ; Geografsko društvo na SR Makedonija, 1968, str. 258-296.

Nekateri elementi geografskega razvoja naselja Ravne po letu 1945. V: Jugovzhodna Koroška. Referati 8. posvetovanja slovenskih geografov, 12. do 14. 9. 1969 na Ravnah na Koroškem. Ljubljana, Geografsko društvo Slovenije, 1970, str. 107-120. 
Socijalno-geografska diferenciacija u gradovima Slovenije. V: Jugoslovanski simpozij o urbani geografiji, Ljubljana, 5.-7. oktober 1970. Ljubljana, Inštitut za geografijo Univerze, 1971, str. 147-162. (Geographica Slovenica, 1)

Oskrba kot dejavnik transformacije mestnega prostora na primeru Maribora. V: Geografski simpozij o severovzhodni Sloveniji, Maribor, 13. do 15. oktobra 1972. Maribor, Obzorja, 1973, str. 33-42. (Geographica Slovenica, 2)

Transformacija vangradskih naselja u gravitacionom području Maribora. Neki elementi pitanja dominance i subdominance. V: Zbornik na Jugoslovenskiot simpozium za problemite na selskite naselbi i zemjodelskoto proizvodstvo, Ohrid, 11-13 maj 1972. Skopje, Sojuz na geografskite institucii na SFRJ; Geografsko društvo na SR Makedonija, 1972, str. 159-168.

Geografski elementi socialnega razlikovanja v mestnem prostoru. V: Socialnogeografski aspekti socialnega razlikovanja med slovenskimi pokrajinami. Geografski simpozij ob 10-letnici Inštituta za geografijo Univerze v Ljubljani, Ljubljana, 7.-8. december 1972. Ljubljana, Inštitut za geografijo Univerze, 1974, str. 121-131. (Geographica Slovenica, 3)

Transformation of agrarian structure in cadastrian parish Zgornje Jablane in Zgornje Dravsko polje. V: Izraba tal v vzhodno-srednje evropskih deželah. 3. konferenca Podkomisije za izrabo tal v vzhodno-srednje evropskih deželah, Maribor, 7.-11. oktober. Ljubljana, Inštitut za geografijo Univerze, 1975, str. 97-99. (Geographica Slovenica, 4)

Die Funktion der Versorgung bei der Ausbildung der Regionalstruktur der Gemeinde Slovenska Bistrica/Slowenien. V: Sozialgeographische Fragestellungen. Beiträge zum Symposium in Ljubljana/Maribor im Oktober 1975. Frankfurt am Main, Universität, Geographisches Institut, 1976, str. 235-247. (Materialien, 5)

Snabdevanje kao faktor prostornog razvoja SR Slovenije. V: Zbornik X jubilarnog kongresa geografa Jugoslavije održanog u Srbiji od 15. do 20. septembra 1976. Beograd, Srpsko geografsko društvo, 1977, str. 314-324.

Aktualni socialnogeografski problemi Zgornjega Posočja. V: Zgornje Posočje. Zbornik 10. zborovanja slovenskih geografov, Tolmin-Bovec, 26.-28. 9. 1975. Ljubljana, Geografsko društvo Slovenije, 1978, str. 127-135. (Soavtorji: Vladimir Klemenčič, Anton Gosar, Marijan M. Klemenčič, Darka Uranjek)

Alpe kot gospodarski prostor. V: Zgornje Posočje. Zbornik 10. zborovanja slovenskih geografov, Tolmin-Bovec, 26.-28. 9. 1975. Ljubljana, Geografsko društvo Slovenije, 1978, str. 251-263.

L'approvvigionamento nel territorio di frontiera. V: Atti del Simposio sui problemi socioeconomici e ambientali degli Sloveni in Italia. Vol. 1. Trieste, Editoriale Stampa Triestina, 1978, str. 137-145. (Gli Sloveni in Italia)

Funkcija oskrbe v regionalnem razvoju zgornjega Posočja. V: Zgornje Posočje. Zbornik 10. zborovanja slovenskih geografov, Tolmin-Bovec, 26.-28. 9. 1975. Ljubljana, Geografsko društvo Slovenije, 1978, str. 193-199.

Geographische Elemente der Funktion Versorgung im Grenzraum entlang der jugoslawisch-italienischen Grenze. V: Socialnogeografski problemi obmestnih in obmejnih 
območij. Medinštitutski simpozij Inštituta za geografijo Univerze v Ljubljani in Geografskega inštituta Univerze v Frankfurtu, Frankfurt, 12.-15. maj 1977, in Medinštitutski simpozij Inštituta za geografijo Univerze v Ljubljani in Gospodarskogeografskega inštituta Univerze v Münchenu, Portorož, 21.-23. februarja 1978. Ljubljana, Inštitut za geografijo Univerze, 1978, str. 21-27. (Geographica Slovenica, 8)

Oskrba kot dejavnik transformacije obmejnih območij. V: Socialnogeografski aspekti obmejnih območij Slovenije. Geografski simpozij ob 15-letnici Inštituta za geografijo Univerze v Ljubljani. Ljubljana, Inštitut za geografijo Univerze, 1978, str. 17-22. (Geographica Slovenica, 6)

Die räumliche Erdbebenwirkung in West Slowenien (im Jahre 1976). V: Socialnogeografski problemi obmestnih in obmejnih območij. Medinštitutski simpozij Inštituta za geografijo Univerze v Ljubljani in Geografskega inštituta Univerze v Frankfurtu, Frankfurt, 12.-15. maj 1977, in Medinštitutski simpozij Inštituta za geografijo Univerze v Ljubljani in Gospodarskogeografskega inštituta Univerze v Münchenu, Portorož, 21.-23. februarja 1978. Ljubljana, Inštitut za geografijo Univerze, 1978, str. 141-149. (Geographica Slovenica, 8)

Regionalna struktura objektov oskrbe v SR Sloveniji. V: II. slovensko-slovaški geografski simpozij, Maribor, 11.-14. december. Ljubljana, Inštitut za geografijo Univerze, 1978, str. 77-84. (Geographica Slovenica, 7)

Einfluß des Tourismus auf die Wandlung der Grenzregionen in Slowenien. Die Versorgungsfunktion als Element des grenzüberschreitenden Fremdenverkehrs. V: Tourism and borders. Proceedings of the Meeting of IGU working group Geography of tourism and recreation, Ljubljana/Trieste, 15.-19. 9. 1978. Frankfurt, Institut für Wirtschaftsund Sozialgeographie der J. W. Goethe-Universität, 1979, str. 31-35. (Frankfurter Wirtschafts- und Sozialgeographische Schriften, 31)

Prostorski problemi Maribora s posebnim ozirom na industrijsko delovno silo. V: Mariborsko Podravje. Zbornik 11. zborovanja slovenskih geografov, Maribor, 28.-30. 6. 1978. Ljubljana, Geografsko društvo Slovenije, 1979, str. 53-63.

Industrijska delovna sila v prostorski strukturi Maribora. V: Urbana in industrijska geografija. Jugoslovanski geografski simpozij, Ljubljana, 8.-10. 11. 1979. Ljubljana, Inštitut za geografijo Univerze Edvarda Kardelja, 1980, str. 43-53. (Geographica Slovenica, 10)

The supply function as a factor in the development of regions along the open border. V: Geografski problemi obmestij. II. poljsko-jugoslovanski seminar, Varšava, 29. 5.3. 6. 1978. Ljubljana, Inštitut za geografijo Univerze Edvarda Kardelja, 1980, str. 159-165. (Geographica Slovenica, 11)

Trgovina in obrt kot dejavnik centralnosti naselij na Gorenjskem. V: Gorenjska. Referati in gradivo na 12. zborovanju slovenskih geografov v Kranju in na Bledu od 15. do 17. oktobra 1981. Ljubljana, Geografsko društvo Slovenije, 1981, str. 228-236.

Socialnogeografski razvoj podeželja v obmejnih predelih Zahodne Slovenije. V: Geografske značilnosti preobrazbe slovenskega podeželja. Gradivo za posvetovanje geografov ob 60-letnici Geografskega društva Slovenije. Ljubljana, Geografsko društvo Slovenije, 1982, str. 111-118. 
Grad kao proces. V: Zbornik XI kongresa geografa SFRJ održanog u SR Crnoj Gori od 28. IX do 2. X 1981. Titograd, Savez geografskih društava SFRJ i Geografsko društvo SR Crne Gore, 1983, str. 275-277.

Regionalni pomen oskrbne funkcije na Dolenjskem. V: Dolenjska in Bela krajina. Prispevki za 13. zborovanje slovenskih geografov v Dolenjskih Toplicah od 12.-14. oktobra 1984. Ljubljana, Geografsko društvo Slovenije, 1984, str. 233-247.

Meja kot faktor razvoja obmejnih območij. V: Zbornik radova sa naučnog simpozijuma Geografski problemi pograničnih regija naše zemlje, Vranje 1987. Vranje, Odsek za geografiju i prostorno planiranje Prirodno-matematičkog fakulteta u Beogradu; Narodni muzej, 1987, str. 13-24.

O sodobni regionalni geografiji. V: Teorija in metodologija regionalne geografije. Jugoslovanski simpozij, Ljubljana, 2. do 3. aprila 1987. Ljubljana, Oddelek za geografijo; Znanstveni inštitut Filozofske fakultete, 1987, str. 23-31. (Dela, 4)

Problematika centralnih naselij na Notranjskem. V: Notranjska. Zbornik 14. zborovanja slovenskih geografov, Postojna, 15.-17. oktobra 1987. Ljubljana, Zveza geografskih društev Slovenije, 1987, str. 219-230. (Soavtorja: Marjan Batagelj, Mauro Hrvatin)

Problematika izrabe mestnega prostora v Mariboru. V: Zbornik XII kongresa geografa Jugoslavije, održanog u Vojvodini od 29.septembra do 6.oktobra 1985. Novi Sad, Savez geografskih društava Jugoslavije; Geografsko društvo Vojvodine, 1987, str. 375-379.

Agricultural land utilization and size structure of holdings in Yugoslavia. V: Socio-economic problems of the development of rural areas. Proceedings of the 4th Polish-Yugoslav geographical seminar, Warszawa - Torún - Stare Pole, Poland 2-9 June, 1986. Warszawa, Polish academy of sciences, Institute of geography and spatial organization, 1989, str. 27-34.

Neki ekonomsko-geografski elementi jugoslovenskog prostora. V: Jugoslovenski geoprostor. Naučni skup, Beograd, 9.-10. jan. 1989. Beograd, Centar za marksizam univerziteta, 1989, str. 232-242.

O regionalni geografiji na ljubljanski univerzi. V: Geografija in aktualna vprašanja prostorskega razvoja. 70 let geografije na ljubljanski univerzi (4.-8. 12. 1989). Ljubljana, Oddelek za geografijo Filozofske fakultete; Znanstveni inštitut, 1989, str. 30-39. (Dela, 6)

Problematika terciarizacije mestnega jedra v Kopru. V: Primorje. Zbornik 15. zborovanja slovenskih geografov, Portorož, 24.-27. oktobra 1990. Ljubljana, Zveza geografskih društev Slovenije, 1990, str. 177-182.

Elementi demogeografskega razvoja v zgradbi Maribora. V: Geografska problematika Severovzhodne Slovenije. Medinštitutski seminar Oddelka za geografijo Pedagoške fakultete v Mariboru in Oddelka za geografijo Filozofske fakultete v Ljubljani ob 30. letnici Oddelka za geografijo v Mariboru. Ljubljana, Oddelek za geografijo Filozofske fakultete Univerze v Ljubljani, 1991, str. 32-52. (Dela, 8)

Najnovejši gospodarskogeografski razvoj v vzhodnoevropskih državah. Analiza novejših razvojnih trendov. V: Zbornik referatov seminarja permanentnega izobraževanja, 5. Ilešičevi dnevi, Ljubljana, 22.-23. 2. 1991. Ljubljana, Oddelek za geografijo Filozofske fakultete Univerze v Ljubljani; Zveza geografskih društev Slovenije, 1991, str.79-85. (Geografija v šoli, 1) 
Geografska problematika narodnostne sestave prebivalstva Ljubljane. V: Geografija in narodnosti, mednarodno posvetovanje 8.-11. september 1993. Ljubljana, Inštitut za geografijo Univerze, 1993, str. 51-63. (Geographica Slovenica, 24)

Nekateri elementi povezovanja Slovenije s sosednjimi državami. V: Geografski aspekti obmejnosti in regionalnega razvoja. Mednarodni medinštitutski seminar Oddelka za geografijo Pedagoške fakultete v Mariboru, Oddelka za geografijo Filozofske fakultete v Ljubljani, Lehrstuhl Wirtschaftsgeographie und Regionalplanung, Universität Bayreuth. Ljubljana, Oddelek za geografijo Filozofske fakultete, 1993, str. 21-31 (Dela, 10)

Regionalni problemi držav Evropske skupnosti. V: Zbornik referatov seminarja permanentnega izobraževanja, 7. Ilešičevi dnevi, Ljubljana, 26.-27. 2. 1993. Ljubljana, Oddelek za geografijo Filozofske fakultete, 1993, str. 29-36. (Geografija v šoli, 3)

Landwirtschaft und ländlicher Raum in Slowenien unter den neuen Bedingungen. V: Der Wandel des ländlichen Raums in Südosteuropa. Ergebnisse der Fachtagung der Südosteuropa-Gesellschaft in Zusammenarbeit mit dem Institut für Länderkunde Leipzig vom 27. bis 29. Juni 1994 in Leipzig. München, Südosteuropa-Gesellschaft; Leipzig, Institut für Länderkunde, 1995, str. 114-121. (Südosteuropa aktuell, 19)

Elementi funkcijske zgradbe Ptuja, Ljutomera in Ormoža. V: Spodnje Podravje s Prlekijo. 17. zborovanje slovenskih geografov, Ptuj, 23.-26. oktober 1996. Ljubljana, Zveza geografskih društev Slovenije, 1996, str. 239-247.

Ljubljana - the capital of Slovenia and an important European gateway. V: Slovenia. A gateway to Central Europe. Published on the occasion of the 28th International geographical congress, The Hague, August 5-10, 1996. Ljubljana, Association of the Geographical Societies of Slovenia, 1996, str. 63-67.

The most recent development trends in Slovenian towns. V: Contemporary city structuring. International geographical insights. Cape Town, Society of South African geographers; International Geographical Union, Commission on urban development and urban life, 1996, str. 93-100.

Razvojni problemi in socialnogeografska analiza naselij Cirkovce, Gorišnica, Stoperce in Sv. Tomaž. V: Spodnje Podravje s Prlekijo. 17. zborovanje slovenskih geografov, Ptuj, 23.-26. oktober 1996. Ljubljana, Zveza geografskih društev Slovenije, 1996, str. 409-445. (Soavtorica Damijana Počkaj Horvat)

Problematika oskrbnih središč v Ljubljani. V: Nove smeri prostorskega razvoja. 6. srečanje geografov iz Univerze v Bayreuthu, Pécsu, Gradcu, Ljubljani in Mariboru, Maribor, 26. in 27. september 1996. Maribor, Pedagoška fakulteta, 1997, str. 249-255.

The influence of the university on the development of Ljubljana. V: Einzelhandelsentwicklung. Vorträge einer Tagung am 24. November 1995. Zielorientierte regionale Geographie. Vorträge einer Tagung am 22. November 1996. Frankfurt am Main, Institut für Kulturgeographie, Stadt- und Regionalforschung der J. W. Goethe-Universität, 1997, str. 213-223. (Materialien, 21)

Some more recent development trends of Slovenian economy. V: The impact of political changes on rural areas of East-Central Europe. Papers of the symposium, Pécs - Kecskemét (Hungary), 2.-6. 6. 1992. Pécs, Janus Pannonius University; Hungarian Academy of Sciences, Centre for Regional Studies, 1997, str. 65-70. 
Analysis of relevant geographic conditions of Slovenia within the context of European spatial development perspectives. V: Zbornik od vtoriot Kongres na geografite na Republika Makedonija, Ohrid 3-5 noemvri 2000. Skopje, Makedonsko geografsko društvo; Prirodno-matematički fakultet, 2001, str. 316-325. (Soavtorja: Andrej Černe, Dušan Plut)

Einkaufszentren in Slowenien. V: Stadt-Umland-Probleme und Entwicklung des großflächigen Einzelhandels in den Ländern Mittel- und Südostereuropas. Hannover, Akademie für Raumforschung und Landesplanung, 2001, str. 187-191. (Arbeitsmaterial, 282) (Soavtor Vladimir Drozg)

Raumordnungspolitische und planungspolitische Behandlung des Einzelhandels in Slowenien. V: Stadt-Umland-Probleme und Entwicklung des großflächigen Einzelhandels in den Ländern Mittel- und Südostereuropas. Hannover, Akademie für Raumforschung und Landesplanung, 2001, str. 183-185. (Arbeitsmaterial, 282)

Regionalno razvojna problematika območja ob slovensko-hrvaški meji. V: Socialnogeografska problematika obmejnih območij ob slovensko-hrvaški meji. Ljubljana, Filozofska fakulteta, Oddelek za geografijo, 2001, str. 29-38. (Dela, 16)

Mesto na prehodu. V: Geografija in njene aplikativne možnosti. Ljubljana, Oddelek za geografijo, Filozofska fakulteta, 2002, str. 435-447. (Dela, 18)

Transformation of block-neighbourhoods in Slovenia. The impact of the market economy. $\mathrm{V}$ : Monitoring cities. International perspectives. Calgary; Berlin, International Geographical Union, Commission on Monitoring Cities of Tomorrow, 2002, str. 373-384.

Funktionale Probleme der Stadtstruktur Sloweniens. V: Die Zukunft der Städte. Vorträge eines Kolloquiums in Frankfurt am Main am 22. und 23. Oktober 2002. Frankfurt am Main, Rhein-Mainische Forschung des Instituts für Kulturgeographie, Stadt- und Regionalforschung und des Instituts für physische Geographie der Johann Wolfgang Goethe-Universität, 2003, str. 17-27. (Rhein-Mainische Forschungen, 124)

Geografski pogledi na regionalno razvojno problematiko obmejnih območij Slovenije. V: Zbornik radova. Međunarodni naučni seminar Regionalno razvojna problematika $\mathrm{BiH}$ i susednjih zemalja u procesu približavanja Evropskoj uniji, Tuzla, 21.-22. 4. 2003. Tuzla, Univerzitet, Prirodno matematički fakultet, Odsjek za geografiju, 2003, str. 85-91.

\section{Povzetki prispevkov na konferencah}

Geografski razvoj naselja Ravne po letu 1945. V: Povzetki referatov v sekcijah. Vodnik po poti ekskurzij. Ljubljana, Geografsko društvo Slovenije, 1969, str. 5-6.

Ljubljana, glavno mesto Slovenije = Ljubljana, the capital of Slovenia. V: Program, povzetki in vodnik. Mednarodno posvetovanje Geografija in narodnosti, Ljubljana, 8.-11. september 1993. Ljubljana, Oddelek za geografijo Filozofske fakultete, 1993, str. $15-20$.

Vodnik po ekskurzijskih poteh. Geografska in narodnostna podoba Ljubljane, glavnega mesta Slovenije $=$ Guides to excursion routes. Geographic and ethnic features of 
Ljubljana, the Slovenian capital. V: Program, povzetki in vodnik. Mednarodno posvetovanje Geografija in narodnosti, Ljubljana, 8.-11. september 1993. Ljubljana, Oddelek za geografijo Filozofske fakultete, 1993, str. 40-41.

Some elements of regional development in Slovenia. V: Regionalism and the Europe of the future. Experiences, challenges and possibilities. Abstracts. Copenhagen, 1994, str. 17.

Globalizacija in razvoj slovenskih mest. V: Bodočnost mest. Povzetki referatov 7. mednarodnega medinštitutskega geografskega seminarja, Oddelek za geografijo Filozofska fakulteta v Ljubljani in Institut für Kulturgeographie, Stadt- und Regionalforschung Univerza v Frankfurtu, Ljubljana 13.-14. april 1999. Ob 80. letnici geografije na ljubljanski univerzi 1919-1999. Ljubljana, Oddelek za geografijo, Filozofska fakulteta, 1999, str. 11.

Funkcijska zgradba Ljubljane. V: Program, povzetki. Ljubljana, Ljubljansko geografsko društvo, 2000, str. 12.

Problematika funkcijske zgradbe Ljubljane. V: Program, povzetki. Ljubljana, Ljubljansko geografsko društvo, 2000, str. 53.

Regionalno razvojna problematika območja ob slovensko-hrvaški meji. V: Socialnogeografska problematika obmejnih območij ob slovensko-hrvaški meji. Povzetki referatov Mednarodnega medoddelčnega geografskega seminarja, Portorož, 18-19. september 2000. Ljubljana, Filozofska fakulteta, Oddelek za geografijo, 2000, str. 8.

Regionalni razvoj Slovenije in njene sosede. V: 12. Ilešičevi dnevi, 27. do 29. september 2001, Filozofska fakulteta, Ljubljana. Ljubljana, Univerza v Ljubljani, Filozofska fakulteta, Oddelek za geografijo, 2001, str. 1.

Regionalno razvojna problematika Slovenije na poti k združeni Evropi. Obmejna območja. V: Priložnosti in možnosti regionalnih struktur na poti k združeni Evropi. Povzetki referatov Mednarodnega medinštitutskega geografskega seminarja, Ljubljana, 12.-13. april 2002. Ljubljana, Oddelek za geografijo, Filozofska fakulteta, 2002, str. 19.

Regionalno razvojna problematika obmejnih območij Slovenije $=$ Regional-development problems of border regions of Slovenia. V: Problemi regionalnog razvoja Hrvatske i susjednih zemalja. Knjiga sažetaka i vodič terenskog izlaska = Regional development problems in Croatia and neighboring countries. Book of abstracts. Field trip guide. Zagreb, Hrvatsko geografsko društvo, 2002, str. 23.

Mesto na prehodu. V: Prospects of applied geography $=$ Geografija in njene aplikativne možnosti. Znanstveno in strokovno posvetovanje. Program, povzetki. Ljubljana, Filozofska fakulteta, Oddelek za geografijo, 2002, str. 76.

Recent development of Slovene towns. V: Cities in transition. Programme, summaries, excursion guides. Ljubljana, Faculty of Arts, 2003, str. 28-29. (Soavtorja: Vladimir Drozg, Dejan Rebernik)

Geographical view of regional developmental problems in boundary-line areas of Slovenia = Geografski pogledi na regionalno razvojne probleme obmejnih območij Slovenije. V: Knjiga sažetaka i vodič terenskog izlaska = Book of abstracts, field trip guide. Tuzla, Univerzitet u Tuzli, Prirodno-matematički fakultet, Odsjek za geografiju, 2003, str. 17. 
Specifični elementi funkcijske zgradbe Ljubljane. V: Geografska problematika Ljubljane in Zagreba. Program, povzetki. Mednarodni medoddelčni seminar. Ljubljana, Oddelek za geografijo, Filozofska fakulteta, 2004, str. 11-12.

Oskrbna funkcija v organizaciji mestnega prostora - na primeru Maribora. V: Evropske razsežnosti urbanizacije. Znanstveni posvet in okrogla miza $\mathrm{v}$ počastitev sedemdesetletnice rednega profesorja dr. Mirka Paka. Program in povzetki. Ljubljana, Univerza, Filozofska fakulteta, Oddelek za geografijo, 2007, str. 13-14.

\section{Diplomsko delo}

Kolonizacija Slovencev v štiri banatska naselja Vršac, Gudurica, Velika Greda, Banatsko Plandište. Ljubljana, 1960.

\section{Doktorska disertacija}

Družbenogeografski razvoj Zg. Dravskega polja. Ljubljana, 1965.

\section{Raziskave, elaborati, študije}

Družbenogeografski razvoj Zg. Dravskega polja. Ljubljana, RSS, 1963, 277 str.

Geografsko proučevanje Porabja na Madžarskem. Nekateri elementi socialno geografskega razvoja in strukture slovenskega Porabja. Ljubljana, Inštitut za geografijo, 1969, 47 str. (Soavtor)

Notranja regionalna diferenciacija mest Slovenije. Ljubljana, RSS, 1969, 81 str.

Projekt nacionalnega atlasa Slovenije. Ljubljana, RSS, 1969, 98 str. (Soavtor)

Socialne deformacije $v$ nekaterih predelih slovenskih mest. Ljubljana, Inštitut za geografijo Univerze v Ljubljani, 1969, 153 str.

Notranja regionalna diferencijacija v mestih Slovenije - na primeru Ljubljane in Maribora. Ljubljana, Biro za regionalno prostorsko planiranje, 1970, 23 str.

Nacionalni atlas Slovenije. 2.del. Ljubljana, RSS, 1971, 111 str. (Soavtor)

Socialnogeografska diferenciacija in transformacija mestnih četrti. Ljubljana, Inštitut za geografijo Univerze v Ljubljani, 1971, 73 str. (Soavtor)

Nekateri geografski elementi oskrbe v trgovskih središčih Ljubljane, Maribora in Kranja. Ljubljana, RSS, 1973, 30 str.

Geografski elementi potrošnje v regionalni strukturi Slovenije. Ljubljana, RSS, 1975, 59 str.

Pregled dosedanjih raziskovalnih rezultatov s področja mestne in socialne geografije. Ljubljana, Inštitut za geografijo Univerze v Ljubljani, 1975, 59 str. (Soavtor)

Regionalno geografska raziskava Zgornjega Posočja. Ljubljana, Inštitut za geografijo Univerze v Ljubljani, 1976, 251 str. (Soavtor) 
Obmejna središča v funkciji oskrbe in potrošnje prebivalstva tostran in onstran meje. Ljubljana, RSS, 1978, 52 str.

Regionalno prostorske posledice potresa v Posočju. Ljubljana, Inštitut za geografijo Univerze v Ljubljani, 1978, 81 str. (Soavtor)

Geografski elementi prostorskega razvoja v mariborski regiji. Ljubljana, RSS, 1979, 203 str.

Južna Evropa. Ljubljana, RSS, 1979, 35 str. (Soavtor)

Manj razvita obmejna območja Zahodne Slovenije. Ljubljana, Inštitut za geografijo Univerze E. Kardelja v Ljubljani, 1980, 259 str. (Soavtor)

Regionalni problemi Gorenjske. Primer gospodarsko razvite mednarodno tranzitne obmejne alpske regije. Ljubljana, Inštitut za geografijo Univerze E. Kardelja v Ljubljani, 1980, 122 str. (Soavtor)

Socialnogeografska in političnogeografska diferenciacija slovenskega etničnega ozemlja. Usmerjanje družbenega in ekonomskega razvoja SRS in SFRJ. Ljubljana, Inštitut za geografijo Univerze E. Kardelja, 1982. (Soavtor)

Atlas SR Slovenije. Ljubljana, Inštitut za geografijo Univerze E. Kardelja, 1983. 172 str. (Soavtor)

Manj razvita obmejna območja Zahodne Slovenije. Ljubljana, Inštitut za geografijo Univerze E. Kardelja v Ljubljani, 1983, 113 str. (Soavtor)

Problematika regionalnega razvoja alpskega sveta v Sloveniji. Ljubljana, Inštitut za geografijo Univerze E. Kardelja v Ljubljani, 1983, 184 str. (Soavtor)

Geografsko proučevanje primernosti organiziranja proizvodnih celic na Koroškem. Sinteza. Ljubljana, Filozofska fakulteta, Znanstveni inštitut in Oddelek za geografijo, 1984. (Soavtor)

Naravna in kulturna dediščina slovenskega naroda. Ptujsko polje. Ljubljana, RSS, 1990. (Soavtor)

Naravna in kulturna dediščina slovenskega naroda. Geografska monografija Slovenije. Ljubljana, RSS, 1993. (Soavtor)

Občina Domžale. Elementi regionalnega razvoja. Ljubljana, Filozofska fakulteta, Oddelek za geografijo, 1993, 28 str. (Soavtor)

Urejanje prostora. Regionalni razvoj. Ljubljana, RSS, 1993. (Soavtor)

Obmejna območja slovenskega alpskega sveta in njih vpetost v evropske integracijske procese. V: Trajnostni razvoj v slovenskem alpskem svetu. Zaključno poročilo. Ljubljana, Oddelek za geografijo, Filozofska fakulteta, Univerza v Ljubljani, 2000, str. 85-93.

Značilnosti regionalnega razvoja in razvojni potenciali Spodnjega Podravja. Zaključno poročilo. Ljubljana, Filozofska fakulteta; Ptuj, Znanstveno-raziskovalno središče Bistra, 2010, 254 str. (Soavtor)

\section{Učbeniki in drugo učno gradivo}

Geografija. Poskusni učbenik. Ljubljana, Mladinska knjiga, 1981, 113 str. (Srednje izobraževanje) (Soavtorji: Slavko Brinovec, Anton Gosar, Marijan M. Klemenčič, 
Vladimir Klemenčič, Franc Lovrenčak, Marija Košak, Jurij Kunaver, Darko Radinja, Igor Vrišer, Marjan Žagar) (1. ponatis, 1982)

Geografija 3. Geografske značilnosti in sodobni problemi Slovenije in Jugoslavije. 1. Spoznavanje in proučevanje domače regije. Ljubljana, Mladinska knjiga, 1981, 74 str. (Srednje usmerjeno izobraževanje) (Soavtorji: Božidar Kert, Marijan M. Klemenčič, Jurij Kunaver)

Geografia. Libro di testo sperimentale. Ljubljana, Mladinska knjiga, 1982, 113 str. (Istruzione media fondo comune di contenuti educativi e istruttivi base) (Soavtorji: Slavko Brinovec, Anton Gosar, Marijan M. Klemenčič, Vladimir Klemenčič, Franc Lovrenčak, Marija Košak, Jurij Kunaver, Darko Radinja, Igor Vrišer, Marjan Žagar)

Geografija 4-1. 4. Geografske značilnosti Jugoslavije. 1. natis. Ljubljana, Mladinska knjiga, 1982, 73 str. (Srednje usmerjeno izobraževanje) (Soavtor Božidar Kert)

Geografija 4-2. Geografske značilnosti in sodobni problemi Slovenije in Jugoslavije. 5. Aktualni geografski procesi in problemi Jugoslavije. 1. natis. Ljubljana, Mladinska knjiga, 1982, 86 str. (Srednje usmerjeno izobraževanje)

Geografija. Države v razvoju in razvite države. Ljubljana, Mladinska knjiga, 1982, 91 str. (Srednje izobraževanje) (Soavtorji: Slavko Brinovec, Marijan M. Klemenčič, Marija Košak, Franc Lovrenčak) (1. izd., 2. natis, 1987; 1. izd., 3. natis, 1989)

Geografija. Geografske značilnosti SFRJ. Ljubljana, Mladinska knjiga, 1983, 96 str. (Srednje izobraževanje) (Soavtorji: Božidar Kert, Avguštin Lah, Marija Košak, Slavko Brinovec) (1. izd., 2. natis, 1989)

Geografija. Geografske značilnosti SFRJ. Delovni zvezek. Ljubljana, Mladinska knjiga, 1983, 115 str. (Srednje izobraževanje) (Soavtorji: Božidar Kert, Marija Košak, Slavko Brinovec) (1985; 1986; 1987; 1988; 2. izd., 1989; 3. izd., 1990)

Geografija 1. Ljubljana, Mladinska knjiga, 1986, 123 str. (Srednje izobraževanje) (Soavtorji: Slavko Brinovec, Anton Gosar, Marijan M. Klemenčič, Vladimir Klemenčič, Jurij Kunaver, Franc Lovrenčak, Dušan Plut, Marija Košak, Darko Radinja, Igor Vrišer) (Dopolnjena izd., 1987; dopolnjena izd., 3. natis, 1989; dopolnjena izd., 4. popravljeni natis, 1990; dopolnjena izd., 5. popravljeni natis, 1991; dopolnjena izd., 6. popravljeni natis, 1992; dopolnjena izd., 7. natis, 1993; dopolnjena izd., 8. natis, 1994)

Geografija. Domača pokrajina. Priročnik za geografsko spoznavanje domače pokrajine. 1. natis. Ljubljana, Mladinska knjiga, 1989, 110 str. (Soavtorji: Andrej Černe, Božidar Kert, Marijan M. Klemenčič, Jurij Kunaver, Franc Lovrenčak)

Geografija. Domača pokrajina. Delovni zvezek za geografsko proučevanje domače pokrajine. 1. natis. Ljubljana, Mladinska knjiga, 1989, 111 str. (Srednje usmerjeno izobraževanje) (Soavtorji: Slavko Brinovec, Andrej Černe, Božidar Kert, Marijan M. Klemenčič, Jurij Kunaver, Franc Lovrenčak)

Geografija Evrope. Ljubljana, Mladinska knjiga, 1994, 201 str. (Soavtorji: Slavko Brinovec, Borut Drobnjak, Jurij Senegačnik) (1. izd., 2. natis, 1995; 1. izd., 3. natis, 1996; 1. izd., 4. natis, 1997; 1. izd., 5. natis, 1998; 1. izd., 6. natis, 1999; 1. izd., 7. natis, 2000; 1. izd., 8. natis, 2001; 1. izd., 9. natis, 2002; 1. izd., 10. natis, 2003; 1. izd., 11. natis, 2004)

Geografija Evrope. Delovni zvezek. 1. natis. Ljubljana, Mladinska knjiga, 1994, 76 str. (Soavtorji: Slavko Brinovec, Borut Drobnjak, Jurij Senegačnik) (2. natis, 1995; 3. 
natis, 1996; 4. natis, 1997; 5. natis, 1998; 6. natis, 1999; 7. natis, 2000; 8. natis, 2001; 9. natis, 2002; 10. natis, 2003)

Obča geografija za 1. letnik srednjih šol. 1. izd. Ljubljana, DZS, 1995, 265 str. (Soavtorji: Marijan M. Klemenčič, Jurij Kunaver, Franc Lovrenčak, Marjan Luževič, Jurij Senegačnik, Aleksander Jakoš) (2. izd., 1996; 3. izd., 1997; 4. izd., 1998; 5. izd., 1999; 6. izd., 2000; 7. izd., 2001)

Obča geografija za 1. letnik srednjih šol. Delovni zvezek. 1. izd. Ljubljana, DZS, 1996, 77 str. (Soavtorji: Borut Drobnjak, Marijan M. Klemenčič, Jurij Kunaver, Franc Lovrenčak, Marjan Luževič, Jurij Senegačnik) (2. izd., 1997; 3. izd., 1998; 4. izd., 1999; 5. izd., 2000; 6. izd., 2001; 7. izd., 2002; 8. izd., 2003)

Geografija za srednje šole. Učbenik za pouk geografije v programih, ki imajo za predmet geografija namenjenih do 140 ur. 1. izd. Ljubljana: DZS, 1997, 285 str. (Soavtorji: Jurij Kunaver, Franc Lovrenčak, Jurij Senegačnik, Borut Drobnjak, Marjan Luževič, Marijan M. Klemenčič) (1. izd., 2. natis, 2000; 1. izd., 3. natis, 2001; 1. izd., 4. natis, 2002; 1. izd., 5. natis, 2003; 1. izd., 6. natis, 2004)

Geografija. 1. izd. Ljubljana, DZS, 1999, 131 str. (Družboslovje) (Soavtorji: Jurij Kunaver, Igor Lipovšek, Marjan Luževič, Marijan M. Klemenčič) (1. izd., 2. natis, 2000; 1. izd., 3. natis, 2004; 1. izd., 4. natis, 2007; 1. izd., 5. natis, 2009; 1. izd., 6. natis, 2010; 1. izd., 7. natis, 2011)

Geografija. Delovni zvezek. 1. izd. Ljubljana, DZS, 1999, 79 str. (Družboslovje) (Soavtorji: Jurij Kunaver, Igor Lipovšek, Marjan Luževič, Marijan M. Klemenčič) (1. izd., 2. natis, 2000)

Obča geografija. Slikovno gradivo iz učbenikov Obča geografija in geografija za srednje šole. CD-ROM za učitelje. Ljubljana, DZS, 2000. (Soavtorji: Jurij Kunaver, Franc Lovrenčak, Ana Vovk Korže, Borut Drobnjak, Marjan Luževič, Marijan M. Klemenčič)

Geografija. Priročnik za učitelje. 1. izd. Ljubljana, DZS, 2001, 176 str. (Družboslovje) (Soavtorji: Jurij Kunaver, Igor Lipovšek, Marjan Luževič, Franci Novak, Senja Požar Podlesnik)

Evropa. Geografija za 2. in 3. letnik gimnazij. 1. izd. Ljubljana, Modrijan, 2006, 161 str. (Soavtorja: Jurij Senegačnik, Igor Lipovšek) (2. izd., 2007; 3. izd., 2008; 4. izd., 2009; 5. izd., 2011; 6. izd., 2012; 7. prenovljena izd., 2015)

Evropa. Geografija za 2. in 3. letnik gimnazij. Delovni zvezek. 1. izd. Ljubljana, Modrijan, 2006, 53 str. (Soavtorja: Jurij Senegačnik, Igor Lipovšek) (2. izd., 2007; 3. izd., 2008; 4. izd., 2009; 5. izd., 2010; 6. izd., 2011; 7. izd., 2012; 8. izd., 2013; 9. izd., 2014; 10. izd., 2015)

\section{Strokovni prispevki}

Nekaj populacijskih problemov Kidričevega. Geografski obzornik 10 (1963), št. 3/4, str. 51-55.

Nekaj geografskih zapažanj s terenskega proučevanja v okolici Novske. Geografski obzornik 13 (1966), št. 2, str. 45-49. 
Zgornje Dravsko polje. Sodobni družbenogeografski procesi. Geografski obzornik 13 (1966), št. 1, str. 16-22.

Nekaj geografskih opažanj iz zahodne okolice Splita. Geografski obzornik 14 (1967), št. 1, str. 8-12.

Excursion 1. Maribor - Rače - Zgornje Jablane - Ptuj - Borl - Visoki Vrh - Ptuj - Maribor. V: Excursion guide and some case studies of land utilization in Slovenia. Ljubljana, Inštitut za geografijo Univerze, 1969, str. 1-5.

Excursion 2. Maribor - Dravograd - Slovenj Gradec - Velenje - Žalec - Trojane. V: Excursion guide and some case studies of land utilization in Slovenia. Ljubljana, Inštitut za geografijo Univerze, 1969, str. 6-11.

Transformation of agrarian structure in cadastrian parish Zgornje Jablane in Zgornje Dravsko polje. V: Excursion guide and some case studies of land utilization in Slovenia. Ljubljana, Inštitut za geografijo Univerze, 1969, str. 39-41.

Nekateri osnovni procesi transformacije mestnega prostora in njegove strukture. Geografski obzornik 19 (1972), št. 3, str. 7-12.

Maribor. V: Vodnik po ekskurziji. XI. zborovanje slovenskih geografov, Maribor, 28.-30. 6. 1978. Ljubljana, Geografsko društvo Slovenije, 1978, str. 22-24.

Vodnik »Problemi človekovega okolja v Sloveniji«. Ljubljana, Inštitut za geografijo Univerze, Zemljepisni muzej, 1978, 29 str. (Soavtorici: Milena Pak, Metka Špes)

Breginjski kot in Kobarid. V: Vodnik po ekskurziji. Ljubljana, Geografsko društvo Slovenije, 1980, str. 32-38.

Vsebinski problemi študija geografije. Geografski obzornik 27 (1980), št. 1/2, str. 30-32. Bibliografija radova sa područja urbane geografije 1945-1981. Ljubljana, 1981, 21 str.

Nekaj misli o položaju v slovenski geografiji. Geografski vestnik 53 (1981), str. 73-83.

Bibliografija del s področja urbane geografije od 1945 do 1982. Ljubljana, Inštitut za geografijo Univerze Edvarda Kardelja, 1983, 59 str.

Industrija v Alpah. Geografski obzornik 31 (1984), št. 4, str. 41-53.

Razvoj prebivalstva v Alpah. Geografski obzornik 31 (1984), št. 4, str. 78-86.

Nekateri ekonomsko-geografski problemi v Jugoslaviji. Geografski obzornik 35 (1988), št. 1, str. 21-36.

Geografski pogled na položaj Jugoslavije v Evropi. Geografski obzornik 37 (1990), št. 1 , str. 24-30.

Kosovo. Geografski obzornik 37 (1990), št. 3/4, str. 4-32.

Some problems of development of the regional structure on the Dravsko polje (Drava Plain) in Slovenia (Yugoslavia). Geographica Iugoslavica 12 (1990), str. 47-52.

Jugoslavija. Agriculture. Eurogeo 1991, št. 5, str. 79-80.

Rast števila in narodnostna sestava prebivalstva Hrvaške, Bosne in Hercegovine ter Vojvodine med letoma 1981 in 1991. Geografski obzornik 39 (1992), št. 3, str. 26-32. (Soavtorica Andrejka Slavec)

Razvoj ameriških mest. V: Ob pacifiški prelomnici. Geografska ekskurzija 1996. Ljubljana, Oddelek za geografijo, Filozofska fakulteta, Univerza v Ljubljani, 1996, str. 26-28.

Simbioza univerze in njenega okolja. Delo 38 (24. apr. 1996), št. 95, str. 6.

Urbane univerze in njihova mesta. Vestnik/Univerza v Ljubljani 27 (1996), št. 5, str. 15. 
Problematika členitve Evrope na osnovne makroregije. Geografija v šoli 6 (1997), št. 2/3, str. 110-112.

Še o geografiji. Delo 39 (6. jan. 1997), št. 3, str. 4. (Soavtorja: Jurij Kunaver, Franc Lovrenčak)

Dravska ravan. V: Slovenija. Pokrajine in ljudje. Ljubljana, Mladinska knjiga, 1998, str. 592-603.

Savska ravan. V: Slovenija. Pokrajine in ljudje. Ljubljana, Mladinska knjiga, 1998, str. 84-93.

Regionalni razvoj obmejnih območij v luči evropskega povezovanja. Geografija v šoli 9 (2000), št. 2, str. 14-19.

Ljubljana je socialno in funkcijsko vedno bolj heterogena. Delo 42 (18. okt. 2000), št. 244, str. 32. (Soavtor Dejan Rebernik)

Regionalni razvoj Slovenije in sosednje države. Geografija v šoli 11 (2002), št. 1, str. 24-32.

Evropa doživlja urbano eksplozijo. Mesta in geografija. Delo 45 (25. avg. 2003), št. 195, str. 9.

Excursion to the Eastern subpannonian Slovenia, 21 August 2003 (Velenje, Maribor, Ptuj). Description of the tour. V: Cities in transition. Programme, summaries, excursion guides. Ljubljana, Faculty of Arts, 2003, str. 85-87.

Sodelovanje slovenskih in nemških geografov. Dela 2007, št. 27, str. 289-303.

Razvojni potenciali Haloz. Geografski obzornik 59 (2012), št. 1/2, str. 4-11.

Haloze pred izzivi prihodnosti. Ugotovitve, predlogi in pobude. Geografski obzornik 59 (2012), št. 1/2, str. 44-47. (Soavtorja: Vladimir Korošec, Simon Kušar)

\section{Sestavki v enciklopedijah in leksikonih}

Enciklopedija Jugoslavije. Izd. v slovenskem jeziku (2. izd.). Zagreb, Jugoslavenski leksikografski zavod, 1983-1989.

Knj. 1 (1983): Ajdovščina, Belec Borut

Knj. 2 (1985): Cerkljansko, Cerkno

Knj. 3 (1987): Čedad (Soavtor), Dravsko polje

Knj. 4 (1989): Grosuplje, Gure

Enciklopedija Jugoslavije. 2. izd. Zagreb, Jugoslavenski leksikografski zavod, 19801990 Knj. 6 (1990): Jeršič Matjaž

Enciklopedija Slovenije. Ljubljana, Mladinska knjiga, 1987-2002.

Knj. 1 (1987): Gornja Radgona (Soavtor)

Knj. 4 (1990): Hrvatska (Soavtor)

Knj. 6 (1992): Ljubljana (Soavtor)

Knj. 8 (1994): Novi Sad, Ormož (Soavtor)

Knj. 9 (1995): Podvelka, Poljčane, Postojnska vrata (Soavtor), Pragersko (Soavtor), Prevalje (Soavtor), Priština, Podravje (Soavtor)

Knj. 10 (1996): Ptuj (Soavtor), Ptujsko polje, Rače (Soavtor), Radlje ob Dravi (Soavtor), Ravne na Koroškem (Soavtor), Razvanje, Ribnica na Pohorju (Soavtor), Ruše (Soavtor) 
Knj. 12 (1998): Selnica ob Dravi, Slivnica pri Mariboru (Soavtor), Slovenija (Soavtor), Slovenska Bistrica (Soavtor), Spodnja Polskava, Spodnje Hoče (Soavtor), Srbija (Soavtor), Starše (Soavtor), Svečina (Soavtor)

Knj. 13 (1999): Šentilj v Slovenskih goricah (Soavtor), Škofljica (Soavtor), Šmartno pod Šmarno goro (Soavtor), Tacen (Soavtor), Trzin

Knj. 14 (2000): Vevče (Soavtor), Vojvodina (Soavtor)

Knj. 15 (2001): Zgornja Kungota, Zgornja Polskava (Soavtor)

Knj. 16 (2002): Klemenčič Marijan Mihael

\section{Knjižna poročila}

Časopis za zgodovino in narodopisje. Geografski obzornik 14 (1967), št. 2, str. 73.

Karl Ganser, Modelluntersuchung zur Dorferneuerung. Münchner Geographische Hefte. Herausgegeben von Prof. dr. W. Hartke in Prof. dr. H. Louis. Redaktor dr. Karl Ganser. Heft 30. Bayerischer Landwirtschaftsverlag München 1967, strani 106, 6 kart v prilogi in 6 kart v tekstu, 16 diagramov ter 32 tabel. Geografski vestnik 39 (1967), str. 194-195.

Vladimir Bračič, Vinorodne Haloze. Socialno-geografski problemi s posebnim ozirom na viničarstvo. Založba Obzorja, Maribor 1967, strani 252, 23 kart, 61 tabel in diagramov, 35 skic, slik in risb. Geografski vestnik 39 (1967), str. 175-177.

Zbornik radova prvog jugoslavenskog simpozija o agrarnoj geografiji u Mariboru od 3. do 5. decembra 1964. Ljubljana 1967, strani 179. Geografski vestnik 39 (1967), str. 177-179.

Borut Belec, Ljutomersko-Ormoške gorice. Geografski obzornik 15 (1968), št. 3/4, str. 44.

Zum Standort der Sozialgeographie. Wolfgang Hartke zum 60. Geburtstag. Beiträge zusammengestellt von K. Ruppert. Münchner Studien zur Sozial- und Wirtschaftsgeographie, Band 4, Verlag Michael Lassleben, Kallmünz/Regensburg 1968, strani 207. Geografski vestnik 40 (1968), str. 167-170. (Soavtor Jakob Medved)

Cvijićev zbornik - u spomen 100. godišnjice njegovog rodjenja. Srpska akademija nauka i umetnosti, Odelenje prirodno-matematičkih nauka. Urednik Milislav Lutovac. Beograd 1968, strani 474. Geografski vestnik 41 (1969), str. 119-122.

Franc Schaffer, Untersuchungen zur sozialgeographischen Situation und regionalen Mobilität in neuen Grosswohngebieten am Beispiel Ulm-Eselsberg. Münchner Geographische Hefte, Heft 32. Michael Lassleben Kallmünz/Regensburg 1968, strani 150, 4 barvne ter 24 črno-belih kart v prilogi. Geografski vestnik 41 (1969), str. 129-131.

Sozialgeographische Probleme Südosteuropas. Münchner Studien zur Sozial- und Wirtschaftsgeographie. Wirtschaftsgeographisches Institut der Universität München. Band 7, Kallmünz/Regensburg 1973. Geografski vestnik 45 (1973), str. 135-136.

Borut Belec, Vinogradništvo kot dejavnik prostorske preobrazbe v Sloveniji, Časopis za zgodovino in narodopisje, Nova vrsta 9 (XLIV), letnik 1973, prvi zvezek, Založba Obzorja Maribor, 1973, str. 139-198, 6 kart med besedilom. Geografski vestnik 46 (1974), str. 153-154. 
Matjaž Jeršič and Vladimir Klemenčič: Topical Problems of Open Boundaries, Confini e Regioni, Instituto di Sociologia Internazionale Gorizia, Trieste 1973, str. 123-133. Geografski vestnik 46 (1974), str. 154-155.

Stadtgeographie in einem neuen Curriculum, dargestellt am Beispiel München, Münchner Geographische Hefte, št. 37, Verlag Michael Lassleben Kallmünz/Regensburg 1973. Geografski vestnik 46 (1974), str. 174.

Planerski atlas Socialističke republike Hrvatske. Republički sekretariat za urbanizam, gradjevinarstvo, stambene i komunalne poslove, Zagreb 1974. Geografski vestnik 47 (1975), str. 198-199.

Istra i njeni razvojni putevi, Ekonomski inštitut Zagreb, Zagreb 1973. Uredila Juraj Paden in Stanko Žuljić. Geografski vestnik 47 (1975), str. 199-200.

Zbornik IX. kongresa geografa Jugoslavije u Bosni i Hercegovini od 24. do 30. 9. 1972. Izdalo Geografsko društvo BiH, Sarajevo 1974. Geografski vestnik 47 (1975), str. 201-203.

Jakob Medved: Svet se spreminja - človek in prehrana. Mladinska knjiga, Ljubljana 1967, str. 111. Geografski vestnik 48 (1976), str. 193.

Geographical papers 2. Institut za geografiju Sveučilišta u Zagrebu, Zagreb 1974. Geografski vestnik 48 (1976), str. 193-194.

Mitko Panov: Socialna geografija i prostorno planiranje na primerot na SR Makedonija. Prirodno-matematički fakultet Skopje, Geografski institut, posebno izdanje, knjiga 3. Skopje 1967, str. 110. Geografski vestnik 48 (1976), str. 194-195.

Sozialgeographische Fragestellungen, Beiträge zum Symposium in Ljubljana/Maribor in Oktober 1975, Materialien 5, Geographisches Institut der Universität Frankfurt, Frankfurt am Main 1976. Geografski vestnik 49 (1977), str. 249-250.

Zlatko Pepeonik: Jugoslavenska ekonomska emigracija u Švedsku, Radovi Instituta za geografiju, br. 13, Zagreb, 1976, str. 5-132. Geografski vestnik 49 (1977), str. 250.

Mitko Panov: Geografija na SR Makedonija, knjiga 1, Skopje, 1976, str. 403. Geografski vestnik 49 (1977), str. 251.

Vasil Gramatikovski: Prirodno-geografski, demografski i imotni karakteristiki na Prespanskata kotlina, Prirodno-metematički fakultet na Univerzitet Kiril i Metodij Skopje, Skopje, 1975, str. 103. Geografski vestnik 49 (1977), str. 251-252.

Milan Vresk: Osnove urbane geografije, Školska knjiga, Zagreb, 1977, str. 127. Geografski vestnik 49 (1977), str. 253.

Dr. Enver Dukagjini: Gradska naselja Metohije (Dukagjini). Prišstina 1978. Univerzitet u Prištini, Prirodno-matematički fakultet, 319 str. Geografski vestnik 51 (1979), str. 193-194.

Atlas sveta za osnovne in srednje šole. Geografski obzornik 27 (1980), št. 1/2, str. 37-38.

Mariborsko Podravje. Zbornik 11. zborovanja slovenskih geografov v Mariboru. Maribor 1979. Izdalo Geografsko društvo Slovenije, str. 160. Geografski vestnik 52 (1980), str. 176-177.

Dr. Branislav Bukurov, Banat i Srem. Matica Srpska, Novi Sad 1978, str. 141. Geografski vestnik 52 (1980), str. 184-185.

Spomen zbornik. Ob 30. obletnici Geografskega društva Hrvatske (1947-1977). Geografsko društvo Hrvatske. Zagreb 1980. Geografski vestnik 52 (1980), str. 185. 
Dr. Jovan D. Marković, Regionalna geografija SFR Jugoslavije, Beograd 1980, str. 938. Geografski vestnik 53 (1981), str. 133-134.

Räumliche Struktur und Prozessmuster in der SR Makedonien. Münchner Studien zur Sozial- und Wirtschaftsgeographie, Band 20, Kallmünz/Regensburg 1980. Geografski vestnik 53 (1981), str. 135-136.

V letu 1983 naj bi izšel prvi zvezek Atlasa SR Slovenije. Geografski obzornik 29 (1982), št. $1 / 2$, str. 51-52.

Dr. Vladimir Bračič, Gozdnate Haloze, Maribor, Založba Obzorja 1982. Geografski obzornik 29 (1982), št. 3/4, str. 43-44.

Geografske značilnosti preobrazbe slovenskega podeželja. Geografski obzornik 29 (1982), št. 3/4, str. 45-46.

Veljko Rogić, Regionalna geografija Jugoslavije, knj. 1, Šolska knjiga, Zagreb 1982, 219 strani. Geografski vestnik 55 (1983), str. 117-118.

Dr. Vladimir Bračič, dr. Avguštin Lah, dr. Igor Vrišer: Sodobni svet, Založba Obzorja, Maribor 1983, str. 746. Geografski vestnik 56 (1984), str. 89-90.

Igor Vrišer: Urbana geografija. Ljubljana 1984, str. 240. Geografski vestnik 56 (1984), str. 90-91.

Zbornik o jugoslovansko-poljskem geografskem seminarju. Geografski vestnik 56 (1984), str. 108-110.

Vrišer Igor: Urbana geografija, Ljubljana 1984, str. 240, grafičnih prilog 62. Geografski vestnik 57 (1985), str. 87-88.

Vladimir Bračič: Dravinjske gorice s Podpohorskimi goricami in Savinskim, Založba Obzorja, Maribor 1985, s. 193. Geografski vestnik 58 (1986), str. 109-110.

Economic Geography of Hungary, Akademiai Kiado, Budapest 1985, str. 450. Geografski vestnik 58 (1986), str. 136-137.

Radovi. Geografski odjel PMF Vseučilišča u Zagrebu, št. 19, 20, 21. Zagreb, 1984, 1985, 1986. Geografski vestnik 59 (1987), str. 174-175.

Elisabeth Lichtenberger, Stadtgeographie. Band 1, Begriffe, Konzepte, Modelle, Prozesse. Teubner Stuttgart 1986. Str. 280, 109 skic in 13 tabel. Geografski vestnik 59 (1987), str. 183-184.

Veliki geografski atlas Jugoslavije. Sveučilišna naklada Liber, Zagreb 1987. Geografski vestnik 60 (1988), str. 167-169.

Znanstvena revija, 1994, Maribor 1995. Geografski vestnik 67 (1995), str. 183-184.

Vladimir Drozg: Morfologija vaških naselij v Sloveniji, Geographica Slovenica 27, Ljubljana 1995. Geografski vestnik 68 (1996), str. 279-281.

Novejša hrvaška geografska periodika. Geografski vestnik 69 (1997), str. 219-222.

Sonaravni razvoj v slovenskih Alpah in sosedstvu. Delo 42 (22. nov. 2000), št. 271, str. 28.

Geografski radovi 1. Univerzitet u Tuzli, Prirodno-matematički fakultet, Odsjek za geografiju, Tuzla 2005, 151 strani, ISSN 1840-0779. Dela 2005, št. 23, str. 271-272.

Revija za geografijo, nova slovenska geografska revija Oddelka za geografijo Filozofske fakultete v Mariboru. Dela 2007, št. 27, str. 307-309.

Revija za geografijo - nova slovenska geografska revija Oddelka za geografijo Filozofske fakultete v Mariboru. Dela 2007, št. 28, str. 412-414. 
Revija za geografijo 1. Maribor 2006: Oddelek za geografijo Filozofske fakultete Univerze v Mariboru, 150 strani, ISSN 1854-665X. Geografski vestnik 79 (2007), št. 1, str. 139-140.

Revija za geografijo 2, Maribor 2006: Oddelek za geografijo Filozofske fakultete Univerze v Mariboru, 166 strani, ISSN 1854-665X. Geografski vestnik 79 (2007), št. 2, str. $164-165$.

Tatjana Kikec (urednica): Pomurje: geografski pogledi na pokrajino ob Muri. Murska Sobota 2009: Zveza geografov Slovenije in Društvo geografov Pomurja, 263 strani, 40 preglednic, 124 slik, ISBN 978-961-269-031-1. Geografski vestnik 81 (2009), št. 1 , str. 113-115.

\section{Uvodniki}

Predgovor. V: Geografski problemi obmestij. II. poljsko-jugoslovanski seminar, Varšava, 29. 5.-3. 6. 1978. Ljubljana, Inštitut za geografijo Univerze Edvarda Kardelja, 1980, str. 7-8. (Geographica Slovenica, 11)

Ob izidu Novic Oddelka za geografijo Filozofske fakultete v Ljubljani. Novice/Univerza v Ljubljani, Filozofska fakulteta, Oddelek za geografijo 1 (1996), št. 1, str. 3.

Predgovor. V: Spodnje Podravje s Prlekijo. 17. zborovanje slovenskih geografov, Ptuj, 23.-26. oktober 1996. Ljubljana, Zveza geografskih društev Slovenije, 1996, str. 5-6.

Nagovor udeležencem 10. Ilešičevih dnevov. Novice/Univerza v Ljubljani, Filozofska fakulteta, Oddelek za geografijo 1997, št. 3, str. 9-11.

Geografija in regionalno planiranje imata veliko skupnega. V: Zbornik mednarodnega strokovnega posveta ob 30. obletnici organiziranega prostorskega planiranja v Sloveniji na državni ravni (1968-1998). Del 1, Prostorsko planiranje na državni in regionalni ravni. Ljubljana, Urad RS za prostorsko planiranje, 1998, str. 79-80.

Uvodnik. V: Razvojne možnosti Slovenije. Ljubljana, Oddelek za geografijo Filozofske fakultete, 1999, str. 5. (Dela, 14)

Grußadressen. V: 75 Jahre Rhein-Mainische Forschung 1925-2000. Frankfurt am Main, Rhein-Mainische Forschung des Instituts für Kulturgeographie, Stadt- und Regionalforschung und des Instituts für physische Geographie der Johann Wolfgang Goethe-Universität, 2001, str. 17-26. (Rhein-Mainische Forschungen, 119) (Soavtor Rudolf Steinberg)

Geografi o Ljubljani. V: Geografija Ljubljane. Ljubljana, Oddelek za geografijo Filozofske fakultete, 2002, str. 7.

Predgovor. V: Priložnosti in možnosti regionalnih struktur na poti k združeni Evropi. Ljubljana, Oddelek za geografijo, Filozofska fakulteta, 2003, str. 7. (Dela, 19)

Preface. Dela 2004, št. 21, str. 9.

Predgovor. Dela 2004, št. 22, str. 5.

Haloze na razvojnem razpotju. Geografski obzornik 59 (2012), št. 1/2, str. 2. 


\section{Poročila o delu}

Poročilo o delu geografskega društva. (Poročilo predsednika UO GDS za obdobje od 21. aprila 1972 do 6. oktobra 1973 na zborovanju v Rogaški Slatini). Geografski vestnik 45 (1973), str. 149-154.

Znanstveno in raziskovalno delo Inštituta za geografijo pri Univerzi v Ljubljani. Nacionalni atlas Slovenije. Geografski vestnik 47 (1975), str. 153-155.

30 let Geografskega društva Hrvatske. Geografski obzornik 24 (1977), št. 3/4, str. 49-50.

Nekaj informacij o delu Zveze geografskih društev Jugoslavije. Geografski obzornik 34 (1987), št. 3, str. 76-78.

Regionalni razvoj. Poročilo o delu za leto 1987. Ljubljana, RSS, 1987. (Urejanje prostora) (Soavtor)

Geografska monografija mesta Maribor. Poročilo o delu v letu 1990. Maribor, Razvojno-raziskovalni inštitut Pedagoške fakultete, 1990. (Soavtor)

Geografska monografija mesta Maribor. Poročilo o delu v letu 1991. Maribor, Razvojno-raziskovalni inštitut Pedagoške fakultete, 1991. (Soavtor)

Geografska monografija mesta Maribor. Poročilo o delu v letu 1992. Maribor, Razvojno-raziskovalni inštitut Pedagoške fakultete, 1992. (Soavtor)

Kratko o Oddelku za geografijo v letu 1996. Novice/Univerza v Ljubljani, Filozofska fakulteta, Oddelek za geografijo, 1997, št. 2, str. 3-4.

Kaj je novega na Oddelku za geografijo. Novice/Univerza v Ljubljani, Filozofska fakulteta, Oddelek za geografijo, 1997, št. 3, str. 3-4.

Poročilo o dejavnosti Oddelka za geografijo Filozofske fakultete Univerze v Ljubljani za študijski leti 1996/97 in 1997/98. Geografski vestnik 70 (1998), str. 235-237.

\section{Poročila o simpozijih}

Jugoslovanski simpozij o problemih podeželskih naselij in agrarne proizvodnje v Ohridu od 11. do 13. maja 1972. Geografski vestnik 44 (1972), str. 216-217.

Jugoslovanski simpozij o urbani in industrijski geografiji v Ljubljani novembra 1979. Geografski obzornik 26 (1979), št. 1/2, str. 54-55.

Obisk hrvatskih geografov v Ljubljani. Geografski obzornik 26 (1979), št. 1/2, str. 52-53.

II. jugoslovanski simpozij o urbani in industrijski geografiji. Geografski vestnik 52 (1980), str. 214-215.

Drugo srečanje sodelavcev PZE za geografijo FF v Ljubljani in Geografskega zavoda PMF v Zagrebu. Geografski obzornik 27 (1980), št. 1/2, str. 43.

Poročilo o jugoslovanskem simpoziju o urbani geografiji. Geografski obzornik 27 (1980), št. $1 / 2$, str. $41-42$.

XI. kongres geografov SFRJ. Geografski obzornik 28 (1981), št. 1/2, str. 61-62.

Tretje srečanje sodelavcev Geografskega zavoda Prirodoslovno matematične fakultete v Zagrebu in Pedagoško znanstvene enote Filozofske fakultete v Ljubljani. Geografski obzornik 28 (1981), št. 1/2, str. 63-64. 
20 let socialne geografije v Sloveniji. Geografski obzornik 29 (1982), št. 3/4, str. 48.

Jugoslovanski simpozij z mednarodno udeležbo »Sociogeografska in ekonomskogeografska proučevanja problemov življenjskega okolja« Ohrid, 23.-26. september 1982. Geografski obzornik 29 (1982), št. 3/4, str. 54.

Posvetovanje o socialnogeografskem proučevanju vplivov melioracij na izrabo zemlje v Spodnji Ščavniški dolini. Geografski obzornik 29 (1982), št. 3/4, str. 52.

Geografska transformacija podeželja. III. jugoslovansko-poljski geografski seminar. Geografski obzornik 30 (1983), št. 1/2, str. 71-72.

Jugoslovanski simpozij o geografskih aspektih večje pridelave hrane v Jugoslaviji, Novi Sad 14.-16. oktober 1982. Geografski vestnik 55 (1983), str. 139-140.

III. jugoslovansko-poljski geografski seminar. Geografski vestnik 56 (1984), str. 123-124.

25. mednarodni geografski kongres je bil v Parizu od 27. do 31.8.1984. Geografski obzornik 31 (1984), št. 1, str. 77-78.

25. mednarodni geografski kongres v Parizu 1984. Geografski vestnik 57 (1985), str. 111 120. (Soavtorji: Borut Belec, Ivan Gams, Matjaž Jeršič, Jurij Kunaver, Franc Lovrenčak) Jugoslovanski simpozij »Opšestveno ekonomski aspekti na migracionite dviženija vo našata zemlja«. Struga 11.-14. 6. 1985. Geografski vestnik 57 (1985), str. 123-124.

IV. poljsko-jugoslovanski geografski seminar. Geografski vestnik 58 (1986), str. 153-154.

Geografski problemi pograničnih regija naše zemlje. Jugoslovanski simpozij, Vranje, 28. do 30. 5. 1987. Geografski vestnik 59 (1987), str. 207-208.

Teorija in metodologija industrijske geografije. Jugoslovanski geografski simpozij, Sarajevo, 3. in 4. oktober 1988. Geografski vestnik 60 (1988), str. 193-194.

V. jugoslovansko-poljski geografski seminar, Zagreb - Koprivnica, 29. 5.-3. 6. 1989. Geografski vestnik 61 (1989), str. 202-203.

Jugoslovanski geoprostor. Beograd 1989. Geografski vestnik 61 (1989), str. 201-202.

Geografija in aktualna vprašanja prostorskega razvoja. 70 let geografije na ljubljanski univerzi, Ljubljana 4.-8. 12. 1989. Geografski vestnik 62 (1990), str. 181-183. (Soavtor Andrej Černe)

Seminar »International center for rural-urban migration in Central and Eastern Europe«, Varšava 6.-7. december 1990. Geografski vestnik 62 (1990), str. 196-197.

Vpliv inovacijskih procesov na preobrazbo pokrajine. Geografski vestnik 62 (1990), str. 195-196.

Medinštitutski seminar oddelkov za geografijo Pedagoške fakultete v Mariboru in Filozofske fakultete v Ljubljani, Maribor, 10. oktober 1991. Geografski vestnik 63 (1991), str. 195-196.

Medoddelčni seminar Oddelkov za geografijo Filozofske fakultete v Ljubljani, Pedagoške fakultete v Mariboru, Katedre za gospodarsko geografijo in regionalno planiranje v Bayreuthu, Inštituta za kulturno geografijo Univerze v Frankfurtu in Geografskega inštituta Pedagoške fakultete v Peči, Bayreuth 12. 11. in Frankfurt 14. 11. 1991. Geografski vestnik 63 (1991), str. 191-192.

Zasedanje »Commission on the urban system and urban development« Mednarodne geografske zveze, Budimpešta, 23.-27. junij 1991. Geografski vestnik 63 (1991), str. $183-185$. 
Mednarodni medinštitutski geografski seminar v Pecsi na Madžarskem, 14.-17. oktober 1992. Geografski vestnik 64 (1992), str. 261-263.

Development perspectives for the wider European territory. Dresden, 15. in 16. 11. 1993. Geografski vestnik 65 (1993), str. 206-209.

Geografski aspekti obmejnosti in regionalnega razvoja, Mednarodni geografski medkatedrski seminar, Maribor 28. 10. 1993. Geografski vestnik 65 (1993), str. 209-210.

Konferenca »Development perspectives of the wider European territory«. Geografski obzornik 41 (1994), št. 1, str. 35.

Der Wandel des ländlichen Raums in Südosteuropa. Spremembe podeželja v Jugovzhodni Evropi, Leipzig, 27.-29. junij 1994. Geografski vestnik 66 (1994), str. 217-218.

Zasedanje Komisije za urbani razvoj in urbano življenje (Urban Development and Urban Life) Mednarodne geografske unije, Berlin, 15. do 20. avgust 1994. Geografski vestnik 66 (1994), str. 218-220.

1. hrvaški geografski kongres, Zagreb, 12. do 13. oktober 1995. Geografski vestnik 67 (1995), str. 214.

17. zborovanje slovenskih geografov na Ptuju. Geografski obzornik 42 (1995), št. 4, str. 3. (Soavtorji: Jurij Kunaver, Bibijana Mihevc, Marjeta Vidmar)

Medinštitutski geografski seminar, Pecs, 27. do 28. april 1995. Geografski vestnik 67 (1995), str. 206-207.

Structuring the Contemporary City. Cape Town, 21. do 25. avgust 1995. Geografski vestnik 67 (1995), str. 209-210.

Medinštitutski geografski seminar v Frankfurtu. Geografski obzornik 44 (1997), št. 1, str. 29.

Problems of megacities. Social inequalities, environmental risks and urban governance; Mexico, D. F. Geografski vestnik 69 (1997), str. 261-262.

Integrated urban system and sustainability of urban life. Geografski vestnik 70 (1998), str. 247-248.

Mednarodni seminar »Bodočnost mest - globalizacija in regionalizacija kot moteča dejavnika«, Ljubljana, 13.-14. 4. 1999. Geografski vestnik 71 (1999), str. 197-198.

Seminar Oddelkov za geografijo Filozofske fakultete Univerze v Ljubljani in Univerze Johann Wolfgang Goethe v Frankfurtu. Geografski obzornik 46 (1999), št. 3, str. 25.

Dva seminarja univerzitetnih oddelkov za geografijo v Ljubljani in v Frankfurtu v letu 2002. Ljubljana, 12.-13. 4. 2002, Frankfurt, Nemčija, 22.-23. 10. 2002. Geografski vestnik 75 (2003), št. 1, str. 127-129.

Simpozij Regionalnorazvojna problematika $\mathrm{BiH}$ in sosednjih držav v procesu približevanja Evropski zvezi, Tuzla, Bosna in Hercegovina, 21.-22. 4. 2003. Geografski vestnik 75 (2003), št. 1, str. 140.

Slovensko-hrvaška medoddelčna srečanja. Portorož, 18.-19. 9. 2000, Pazin, 5.-6. 4. 2002. Geografski vestnik 75 (2003), št. 1, str. 126-127.

Bodočnost mest - vpliv globalizacije in regionalizacije kot moteča elementa. Dela 2004, št. 22 , str. 143 .

Geografska problematika Ljubljane in Zagreba. Dela 2004, št. 22, str. 155.

Geografska problematika Ljubljane in Zagreba, Ljubljana, 15.-16. 4. 2004. Geografski vestnik 76 (2004), št. 1, str. 113-114. 
Simpozij Regionalnorazvojna problematika BiH in sosednjih držav v procesu približevanja Evropski zvezi, Tuzla, Bosna in Hercegovina, 21.-22. 4. 2003. Geografski vestnik 75 (2003), št. 1, str. 140.

Monitoring cities of tomorrow. Meeting of Urban Commission C 19 International Geographical Union. Dela 2004, št. 22, str. 152.

Priložnosti in možnosti regionalnih struktur na poti k združeni Evropi. Dela 2004, št. 22, str. 148.

Socialnogeografska problematika obmejnih območij ob slovensko-hrvaški meji. Dela 2004, št. 22, str. 144.

Slovenska politična geografija in podeželje na razpotju. Mednarodni znanstveni posvet v počastitev 80. letnice dr. Vladimirja Klemenčiča, Ljubljana, 5.-6. oktober 2006. Geografski vestnik 78 (2006), št. 2, str. 129.

\section{Biografski zapisi}

Umrl je prof. dr. Marjan Žagar (1920-1980). Geografski vestnik 53 (1981), str. 153-155. Prof. dr. Branislavu Bukurovu v spomin. Geografski vestnik 58 (1986), str. 148-149.

Prof. dr. Vladimir Klemenčič - šestdesetletnik. Geografski vestnik 58 (1986), str. 145-148.

Šestdeset let prof. dr. Božidarja Kerta. Geografski vestnik 60 (1988) str. 181-182.

Vladimir Bračič sedemdesetletnik. Delo 31 (28. sep. 1989), št. 225, str. 11.

Vladimir Bračič - sedemdesetletnik. Geografski obzornik 36 (1989), št. 2, str. 40-41.

Prof. dr. Matjaž Jeršič - šestdesetletnik. Geografski vestnik 66 (1994), str. 192-195.

Vladimir Bračič. Delo 38 (6. jun. 1996), št. 129, str. 2.

Prof. Vladimir Klemenčič - sedemdesetletnik. Delo 38 (17. jul. 1996), št. 163, str. 2.

Sedemdesetletnica magistra Ferda Šiliha. Geografski vestnik 68 (1996), str. 286-287.

Vladimir Klemenčič in socialna geografija. Novice/Univerza v Ljubljani, Filozofska fakulteta, Oddelek za geografijo, 1997, št. 3, str. 12-16.

Dr. Mitku Panovu v spomin. Skopje, junij 2000. Geografski vestnik 75 (2003), št. 1, str. 125.

Profesor Borut Belec, sedemdesetletnik. Večer 57 (24. jan. 2001), št. 19, str. 16.

Ludviku Olasu v spomin. Maribor, 17. 12. 2002. Geografski vestnik 75 (2003), št. 1, str. $129-130$.

Zlata plaketa Univerze v Ljubljani prof. dr. Klausu Wolfu. Dela 2004, št. 22, str. 169-170. Umrl je dr. Zlatko Pepeonik. Zagreb, Hrvaška, 20. 1. 2004. Geografski vestnik 76 (2004), št. 1 , str. 103-104.

Akademik prof. dr. Anton Melik kot javni delavec. Glasnik Slovenske matice 29/31 (2005/2007), št. 1/3, str. 195-197.

Profesor Borut Belec, osemdesetletnik. Dela 2010, št. 34, str. 245-246.

Dr. Borut Belec - osemdesetletnik. Večer 67 (18. jan. 2011), št. 14, str. 15. 


\section{Uredniško delo}

Dela. ISSN 0354-0596. Ljubljana, Oddelek za geografijo Filozofske fakultete Univerze v Ljubljani. (Glavni urednik 1985-1993, odgovorni urednik 2003-2005, član uredniškega odbora 1994-1999, 2006-2014)

Geographica Iugoslavica. ISSN 0351-3238. Ljubljana, Zveza geografskih društev Jugoslavije, 1978-1990. (Glavni urednik 1984-1987, odgovorni urednik 1990, član uredniškega odbora 1983, 1988-1989)

Geographica Slovenica. Ljubljana. ISSN 0351-1731. Inštitut za geografijo Univerze v Ljubljani, 1972-2002. (Urednik 1974, 1977-1982)

Pregled dela Inštituta za geografijo Univerze v Ljubljani v letih 1962-1972. Ljubljana, Inštitut za geografijo Univerze, 1972, 59 str.

Strokovno poročilo o terenskih vajah v ZR Nemčiji, Belgiji in na Nizozemskem od 24. maja do 8. junija 1972. Ljubljana, Univerza, Inštitut za geografijo Univerze; Filozofska fakulteta, Oddelek za geografijo, 1973. 58 str.

Pregled dela Inštituta za geografijo Univerze v Ljubljani v letih 1972-1976. Ljubljana, Inštitut za geografijo Univerze, 1977, 59 str.

Geografska problematika izbranih območij Zvezne republike Nemčije. Poročilo s strokovne ekskurzije študentov geografije po ZRN od 22. 9. do 4. 10. 1986. Ljubljana, Filozofska fakulteta, Oddelek za geografijo, 1987, 27 str.

Slovenia, geographic aspects of a new independent European nation. Ljubljana, Zveza geografskih društev Slovenije, 1992, 99 str. (Sourednik)

Geografija in narodnosti. Mednarodno posvetovanje, Ljubljana 8. - 11. september 1993. Program, povzetki in vodnik = Symposium on ethnicity and geography, Ljubljana, September 8-11, 1993. Programme, abstracts and guide. Ljubljana, Oddelek za geografijo Filozofske fakultete, 1993, 49 str. (Sourednik)

Kommunalwirtschaftliches Entwicklungskonzept für die Gemeinde Domžale/Slowenien. Ergebnisse eines gemeinsamen Gelände-Praktikums der Universitäten Bayreuth und Ljubljana in enger Kooperation mit der Wirtschaft. Bayreuth, Universität, Lehrstuhl Wirtschaftsgeographie und Regionalplanung, 1994, 109 str. (Arbeitsmaterialien zur Raumordnung und Raumplanung, 140) (Sourednik)

Maribor - Marburg. Prispevki h geografiji prijateljskih mest v Sloveniji in Nemčiji. Maribor, Pedagoška fakulteta, 1994, 271 str. (Sourednik)

Marburg - Maribor. Geographische Beiträge über die Partnerstädte in Deutschland und Slowenien, Marburg am Lahn, Marburger Geographische Gesellschaft, 1994, 282 str. (Marburger Stadtschriften zur Geschichte und Kultur, 48) (Sourednik)

Marburg - Maribor. Geographische Beiträge über die Partnerstädte in Deutschland und Slowenien. Marburg/Lahn, Marburger Geographische Gesellschaft, 1994, 182 str. (Marburger Geographische Schriften, 126) (Sourednik)

Regionalnogeografska monografija Slovenije. Del 1, Visokogorski alpski svet. Ljubljana, Znanstvenoraziskovalni center SAZU, Geografski inštitut, 1996, 105 str. (Sourednik) Regionalnogeografska monografija Slovenije. Del 2, Zahodni predalpski svet. Ljubljana, Znanstvenoraziskovalni center SAZU, Geografski inštitut, 1996, 101 str. (Sourednik) 
Regionalnogeografska monografija Slovenije. Del 3, Ljubljanska kotlina. Ljubljana, Znanstvenoraziskovalni center SAZU, Geografski inštitut, 1996, 124 str. (Sourednik)

Spodnje Podravje s Prlekijo. Možnosti regionalnega in prostorskega razvoja. 17. zborovanje slovenskih geografov, Ptuj, 23.-26. oktober 1996. Ljubljana, Zveza geografskih društev Slovenije, 1996, 445 str.

Bodočnost mest. Povzetki referatov 7. mednarodnega medinštitutskega geografskega seminarja, Oddelek za geografijo Filozofska fakulteta v Ljubljani in Institut für Kulturgeographie, Stadt- und Regionalforschung Univerze v Frankfurtu, Ljubljana 13.-14. april 1999. Ob 80. letnici geografije na ljubljanski univerzi 1919-1999. Ljubljana, Oddelek za geografijo, Filozofska fakulteta, 1999, 28 str. (Sourednik)

Protokol terenskih vaj v obmejna območja Avstrije, Madžarske, Slovaške, Češke in Poljske, 24.-28. maj 1999. Ljubljana, Filozofska fakulteta, Oddelek za geografijo, 1999, 32 str. (Sourednik)

Socialnogeografska problematika obmejnih območij ob slovensko-hrvaški meji. Povzetki referatov Mednarodnega medoddelčnega geografskega seminarja, Portorož, 18.-19. september 2000. Ljubljana, Filozofska fakulteta, Oddelek za geografijo, 2000, 24 str. (Sourednik)

Geografija Ljubljane. Ljubljana, Oddelek za geografijo Filozofske fakultete, 2002, 237 str.

Priložnosti in možnosti regionalnih struktur na poti k združeni Evropi. Povzetki referatov Mednarodnega medinštitutskega geografskega seminarja, Ljubljana, 12.-13. april 2002. Ljubljana, Oddelek za geografijo, Filozofska fakulteta, 2002, 37 str. (Sourednik)

Cities in transition. Programme, summaries, excursion guides. Ljubljana, Faculty of Arts, 2003, 112 str. (Sourednik)

Geografska problematika Ljubljane in Zagreba. Program, povzetki. Ljubljana, Oddelek za geografijo, Filozofska fakulteta, 2004, 27 str. (Sourednik)

\section{Mentor pri doktorskih disertacijah}

Drozg, Vladimir. Morfologija vaških naselij v Sloveniji. Ljubljana, 1992.

Slavec, Andrejka. Geografija Kranja. Ljubljana, 1997.

Rebernik, Dejan. Socialna geografija Ljubljane. Ljubljana, 1999.

Rejec Brancelj, Irena. Agrarnogeografske značilnosti slovenskih pokrajin z vidika varstva okolja. Ljubljana, 1999. (Somentor)

Nurković, Rahman. Vpliv industrije na razvoj Tuzlanske kotline = Uticaj industrije na razvoj Tuzlanske kotline. Ljubljana, 2001.

Korošec, Vladimir. Razvojni problemi podeželskih naselij Spodnjega Podravja. Ljubljana, 2002.

Senegačnik, Jurij. Geografija Evrope v šolskih učbenikih evropskih držav. Ljubljana, 2005. 


\section{Mentor pri magistrskih delih}

Gosar, Anton. Geografska opredelitev regionalnega migracijskega cikla zdomcev med SR Slovenijo in inozemstvom. Ljubljana, 1979. (Somentor)

Orožen Adamič, Milan. Geografski učinki potresov v letu 1976 v Sloveniji. Ljubljana, 1979.

Šilih, Ferdo. Geografski elementi preobrazbe Slovenskih goric v mariborski občini. Maribor, 1980.

Slavec, Andrejka. Industrija Maribora. Ljubljana, 1992.

Šolar, Renata. Storitvene dejavnosti v mestih. Na primeru Ljubljane. Ljubljana, 1995.

Krajnc, Dimitrij. Strukturne spremembe v kmetijstvu Severovzhodne Slovenije po letu 1990. Ljubljana, 1999. (Somentor)

\section{Mentor pri diplomskih delih}

Došler, Veronika. Geografski razvoj Rogaške Slatine. Ljubljana, 1972.

Hribar-Tomažič, Veronika. Dornberška mikroregija. Ljubljana, 1973.

Guna, Andrej. Geografski razvoj in struktura Zagorja ob Savi. Ljubljana, 1973.

Marolt, Darja. Geografski razvoj naselja Polzela. Celje, 1975.

Primožič, Marko. Bivša občina Vransko. Velenje, 1976.

Miklavc, Janja. Geografija doline Rečice pri Laškem. Transformacija pokrajine pod vplivom spremembe funkcije. Ljubljana, 1976.

Žgalin, Marija. Geografija SZ obrobja Ljubljane na primeru naselij Tacen in Šmartno pod Šmarno goro. Ljubljana, 1976.

Krivic, Blaž. Socialno deformirani predeli Ljubljane na območju občin Ljubljana Bežigrad in Moste. Ljubljana, 1976.

Motik, Dragica. Ekonomsko-geografski problemi obmejnih območij SRH. Ljubljana, 1977.

Genorio, Rado. Geografija poslovnega središča v Ljubljani. Ljubljana, 1977.

Sajko-Ocepek, Marija. Geografija Velenja. Velenje, 1977.

Lotrič, Milan. Geografski problemi obrobja starega mestnega jedra na primeru Trubarjeve ceste v Ljubljani. Ljubljana, 1977.

Rus, Angelca. Suha krajina. Geografski opis. Ljubljana, 1977.

Kaučič, Ljubica. Demogeografski problemi Ljubljane. Ljubljana, 1978.

Ileršič-Puhar, Marija. Geografija naselja Medvode. Ljubljana, 1978.

Ivančič, Marjeta. Brežice. Ljubljana, 1979.

Dakskobler, Marija. Geografija infrastrukture v obmejnem območju ob jugoslovanskoitalijanski meji. Ljubljana, 1979.

Sajko, Bibijana. Geografski problemi naselja Kidričevo. Ljubljana, 1979.

Zakotnik, Tatjana. Geografsko ovrednotenje strukture ožjega mestnega predela Ljubljana-Bežigrad. Ljubljana, 1979.

Sajovic, Andreja. Geografsko ovrednotenje strukture ožjega mestnega predela LjubljanaŠiška. Ljubljana, 1979. 
Korošec, Vladimir. Ptujsko polje. Agrarno-geografski problemi. Ljubljana, 1979.

Radoman, Drago. Tržna agrarna produkcija v Ljubljani. Ljubljana, 1979.

Pirš, Slavi. Geografska problematika izrabe in funkcijske členitve južnega dela Ljubljane. Del občine Vič in del starega mestnega jedra. Ljubljana, 1980.

Perovšek, Anton. Urbanizacija vzhodnega dela Ljubljanskega barja. Desni breg Ljubljanice. Ljubljana, 1980.

Vidmar, Jana. Geografija Mengša. Ljubljana, 1981.

Kurinčič, Sonja. Obrt kot dejavnik oblikovanja mestnega prostora. Mestni predel občine Ljubljana-Bežigrad. Ljubljana, 1981.

Novak, Urška. Obrt kot dejavnik oblikovanja mestnega prostora na primeru občine Ljubljana-Center. Ljubljana, 1981.

Colja, Sonja. Obrt kot dejavnik oblikovanja mestnega prostora na primeru občine Ljubljana-Moste. Ljubljana, 1981.

Gliha-Tomšič, Cirila. Obrt kot dejavnik oblikovanja mestnega prostora na primeru občine Ljubljana-Vič-Rudnik. Ljubljana, 1981.

Kolenc-Kolnik, Karmen. Zdraviliški turizem celjske regije s posebnim ozirom na zdravilišče Dobrna. Celje, 1981.

Podgoršek, Vili. Geografska problematika agrarne proizvodnje na južnem Dravskem polju. Ljubljana, 1982.

Zakonjšek, Bronica. Obmestje Celja. Urbanizacija. Ljubljana, 1982.

Mikuž, Herman. Obrt kot dejavnik oblikovanja mestnega prostora. Mestni predel občine Ljubljana-Šiška. Ljubljana, 1982.

Vodeb, Dušan. Geografija Šentjurja. Ljubljana, 1983.

Gojčič, Stojan. Geografija zahodnega dela Dravskega polja. Rače, 1983.

Hrovatič, Erika. Obrt kot dejavnik oblikovanja mestnega prostora na primeru občine Celje. Ljubljana, 1983.

Ulčar, Vida. Razvoj naselij na jugovzhodnem obmestju Ljubljane. Lavrica, Škofljica, Šmarje-Sap. Ljubljana, 1983.

Smole, Marjeta. Urbanizacija zahodnega dela Ljubljanskega barja. Ljubljana, 1983.

Pušnik-Bruderman, Milka. Geografska problematika najnovejše upravno politične delitve mariborskih občin. Maribor, 1985.

Zupančič, Mojca. Črnuče. Razvoj obmestnega naselja Ljubljane. Ljubljana, 1987.

Lapuh, Andrej. Centralna naselja v občini Vič-Rudnik. Ljubljana, 1988.

Florjanc, Aleš. Geografija Novega mesta. Ljubljana, 1988.

Bertoncelj, Anita. Geografska problematika prenove starega jedra Kranja. Kranj, 1990.

Bohinc, Ivanka. Geografska problematika terciarnih dejavnosti v regionalni strukturi občine Šk. Loka. Škofja Loka, 1990.

Šeruga, Igor. Gospodarskogeografski oris ptujske občine. Ljubljana, 1990.

Toth, Kornelija. Geografija Lendave. Ljubljana, 1991.

Benčič, Tanja. Geografija občine Izola. Ljubljana, 1992.

Petrič, Marijana. Geografija Velikolaške pokrajine. Ljubljana, 1992.

Rupnik, Liljana. Gospodarska zgradba mestnega dela občine Ljubljana Moste-Polje. Ljubljana, 1992. 
Kete, Dolores. Geografija Ajdovščine. Ljubljana, 1994.

Homar, Andrej. Razvoj naselij na vzhodnem delu Bistriške ravnine med Rodico in Duplico. Ljubljana, 1995.

Šarman, Sandi. Geografija Šmarsko-Rogaškega podolja. Velenje, 1996.

Kofol, Tomaž. Mestna geografija. Geografija Tolmina. Nova Gorica, 1996.

Kunstelj, Tea. Novejši razvoj naselij Tacen in Šmartno pod Šmarno goro. Ljubljana, 1996.

Boltin, Tanja. Geografska podoba občine Litija s poudarkom na industriji. Litija, 1997.

Krumpak, Andrej. Kozjansko. Dejavniki regionalnega razvoja. Ljubljana, 1997.

Simonič, Monika. Regionalna analiza občine Sveti Jurij ob Ščavnici. Ljubljana, 1997.

Demšar, Simon. Regionalno-razvojna vprašanja Notranjske. Ljubljana, 1997.

Burkeljca, Milan. Geografija Kamnika. Kamnik, 1998.

Šlegel-Florjančič, Saša. Geografija Krope. Zg. Lipnica, 1998.

Marjanovič, Marija. Geografija občine Cerklje na Gorenjskem. Kranj, 1998.

Kočevar, Zdenka. Geografija občine Kranjska Gora. Jesenice, 1998.

Komovec, Aleksander. Geografija severozahodnega obmestja Kranja. Spodnja in Zgornja Besnica. Kranj, 1998.

Snoj, Damjan. Geografija občine Škofljica. Najnovejše smernice razvoja. Ljubljana, 1999.

Šuler, Ariana Nina. Regionalna geografija občine Medvode. Ljubljana, 1999.

Draksler, Katja. Geografska problematika regionalnega razvoja Zasavja. Zagorje, Trbovlje, Hrastnik. Ljubljana, 2000.

Uljan, Mile. Novejši regionalni razvoj občine Ilirska Bistrica. Kuteževo, 2000.

Malnarič, Nevenka. Problematika regionalnega razvoja v občini Semič. Semič, 2000.

Jelčič, Mojca. Turizem v Evropski uniji. Ljubljana, 2000.

Dimc, Darja. Geografija občine Mengeš. Ljubljana, 2001.

Dolenc, Aleš. Regionalni razvoj severnega dela Ljubljanskega polja. Ljubljana, 2001.

Mali, Petra. Oskrba na Gorenjskem. Ljubljana, 2002.

Pecin, Tatjana. Regionalno razvojna problematika vzhodnega obrobja Ljubljane. Ljubljana, 2002.

Boben, Marcela. Somestje Radovljica-Lesce. Ljubljana, 2002.

Čemažar, Mika. Vilske četrti v Ljubljani. Ljubljana, 2002.

Šifrar, Saša. Regionalno-razvojna problematika občine Gorenja vas-Poljane. Ljubljana, 2003.

Gnilšek, Izidor. Regionalno razvojna problematika Ptujskega polja. Ljubljana, 2004.

(Bibliografijo pripravila Ida Knez Račič) 